\title{
Quantitative Single-Cell-Reverse Transcription-PCR Demonstrates That A-Current Magnitude Varies as a Linear Function of shal Gene Expression in Identified Stomatogastric Neurons
}

\author{
Deborah J. Baro, ${ }^{1}$ Robert M. Levini, ${ }^{1}$ Marshall T. Kim, ${ }^{1}$ Allan R. Willms, ${ }^{2}$ Cathy Cole Lanning, ${ }^{1}$ \\ Hilda E. Rodriguez, ${ }^{1}$ and Ronald M. Harris-Warrick ${ }^{1}$ \\ ${ }^{1}$ Section of Neurobiology and Behavior and ${ }^{2}$ Center for Applied Mathematics, Cornell University, Ithaca, New York 14850
}

\begin{abstract}
Different Shaker family $\alpha$-subunit genes generate distinct voltage-dependent $\mathrm{K}^{+}$currents when expressed in heterologous expression systems. Thus it generally is believed that diverse neuronal $\mathrm{K}^{+}$current phenotypes arise, in part, from differences in Shaker family gene expression among neurons. It is difficult to evaluate the extent to which differential Shaker family gene expression contributes to endogenous $\mathrm{K}^{+}$current diversity, because the specific Shaker family gene or genes responsible for a given $\mathrm{K}^{+}$current are still unknown for nearly all adult neurons. In this paper we explore the role of differential Shaker family gene expression in creating transient $\mathrm{K}^{+}$current $\left(I_{A}\right)$ diversity in the 14-neuron pyloric network of the spiny lobster, Panulirus interruptus. We used two-electrode voltage clamp to characterize the somatic $I_{A}$ in each of the six different cell types of the pyloric network. The size, voltage-dependent properties, and kinetic properties of the somatic $I_{\mathrm{A}}$ vary signif-
\end{abstract}

icantly among pyloric neurons such that the somatic $I_{A}$ is unique in each pyloric cell type. Comparing these currents with the $I_{\mathrm{A}} \mathrm{s}$ obtained from oocytes injected with Panulirus shaker and shal cRNA (lobster $I_{\text {shaker }}$ and lobster $I_{\text {shal }}$, respectively) reveals that the pyloric cell $I_{A} s$ more closely resemble lobster $I_{\text {shal }}$ than lobster $I_{\text {shaker }}$ Using a novel, quantitative single-cellreverse transcription-PCR method to count the number of shal transcripts in individual identified pyloric neurons, we found that the size of the somatic $I_{\mathrm{A}}$ varies linearly with the number of endogenous shal transcripts. These data suggest that the shal gene contributes substantially to the peak somatic $I_{\mathrm{A}}$ in all neurons of the pyloric network.

Key words: quantitative; single-cell-RT-PCR; stomatogastric; transient potassium current; Shaker family; potassium channel; gene regulation; Kv; transcriptional control; pyloric network; shal; identified neuron; noncompetitive PCR; invertebrate
The components of an electrically excitable system, be it a heart or a cortical circuit, possess unique electrophysiological phenotypes that are required for the proper performance of that system. In many instances, differences in the amount and/or properties of the transient $\mathrm{K}^{+}$current $\left(I_{\mathrm{A}}\right)$ help to establish these essential cell-specific phenotypes (Connor, 1975; Cassell and McLachlan, 1986; Cassell et al., 1986; Premack et al., 1989; Serrano and Getting, 1989; Hamill et al., 1991; Furakawa et al., 1992; Tierney and Harris-Warrick, 1992; Liu et al., 1993; Banks et al., 1996; Massengill et al., 1997). The functional consequences of $I_{\mathrm{A}}$ heterogeneity are evident in the pyloric central pattern generator.

The 14-neuron pyloric network, located in the stomatogastric ganglion of the spiny lobster, Panulirus interruptus, is a model system for neural circuits that generate rhythmic, cyclic movements like locomotion, respiration, and mastication (Selverston and Moulins, 1987; Harris-Warrick et al., 1992; Simmers et al., 1995; Marder and Calabrese, 1996). In these types of systems, muscles must contract in proper succession to perform a motor task correctly. The order and timing of muscle contraction de-

Received March 4, 1997; revised May 28, 1997; accepted June 17, 1997.

This work was supported by the Human Frontier Science program; National Institutes of Health Grants NS25915, NS35631, and NS17323; Office of Naval Research Grant N00014-95-1-0292 to R.H.-W.; and a Hughes undergraduate fellowship to H.E.R. We thank our anonymous reviewers, Ole Kiehn, Scott Hooper, Thomas Podleski, Jack Peck, Jenifer Levini, Amir Ayali, Ronald Hoy, Bruce Johnson, and David Deitcher for helpful comments on this manuscript.

Correspondence should be addressed to Dr. Deborah J. Baro, Section for Neurobiology and Behavior, Cornell University, Seeley G. Mudd Hall, Ithaca, NY 14853.

Copyright (C) 1997 Society for Neuroscience $\quad 0270-6474 / 97 / 176597-14 \$ 05.00 / 0$ pend on when the different pyloric network neurons fire bursts of action potentials. The burst phase of the various pyloric neurons is partially determined by the amount and specific properties of the $I_{\mathrm{A}}$ present in each cell. For example, during an ongoing motor pattern the lateral pyloric (LP) and pyloric constrictor (PY) neurons are simultaneously released from synaptic inhibition and display postinhibitory rebound. The LP rebounds faster and fires first, partly because it has a smaller $I_{\mathrm{A}}$ at any given physiological voltage (Hartline, 1979; Graubard and Hartline, 1991; Hartline and Graubard, 1992; Tierney and Harris-Warrick, 1992; HarrisWarrick et al., 1995a,b). Thus, cell-specific differences in the $I_{\mathrm{A}}$ strongly influence the order and timing of neuronal firing and muscle contraction.

How is $I_{\mathrm{A}}$ heterogeneity established in this system? Constitutive differences in post-translational modifications could generate cell-specific differences in the $I_{\mathrm{A}}$, because the $I_{\mathrm{A}} \mathrm{s}$ in pyloric neurons can be differentially altered by the same neuromodulator. For instance, dopamine shifts the voltages of the somatic $I_{\mathrm{A}} \mathrm{s}$ of half activation in the depolarizing direction in the LP and PY cells (Harris-Warrick et al., 1995a,b) and in the hyperpolarizing direction in the pyloric dilator (PD) cell (Levini et al., 1996; P. Kloppenburg, unpublished data). On the other hand, differential gene expression also might produce $I_{\mathrm{A}}$ heterogeneity.

In arthropods, A-channel $\alpha$-subunits are encoded by two Shaker family genes, shaker and shal (Salkoff et al., 1992; M. Kim et al., 1995, 1996; Tsunoda and Salkoff, 1995a,b; Baro et al., 1996a) (also see Results). A single multimeric A-channel contains either shaker or shal $\alpha$-subunits, but never a combination of the two (Covarrubias et al., 1991; Li et al., 1992; Sheng et al., 1993; 
Wang et al., 1993; Deal et al., 1994; Lee et al., 1994; Shen et al., 1995; Xu et al., 1995). In addition to $\alpha$-subunits, arthropod A-channels may contain $\beta$-subunits, $\gamma$-subunits, and/or other auxiliary proteins (Zhong and Wu, 1993; Chouinard et al., 1995; Jegla and Salkoff, 1997; Tejedor et al., 1997). For the purposes of this paper, we will define an A-channel by the type of Shaker family $\alpha$-subunit it possesses. Because all pyloric neurons express both the shaker and shal genes (Baro et al., 1996b) (also see Results), we previously hypothesized that varying mixtures of shaker and shal channels carry the somatic $I_{\mathrm{A}}$ in each cell type. Differences in the somatic $I_{\mathrm{A}}$ between cell types could be obtained by varying the fraction of shaker versus shal A-channels.

Like most adult systems, the lobster pyloric network is genetically intractable, so it is difficult to judge the extent to which differences in Shaker family gene expression contribute to $I_{\mathrm{A}}$ heterogeneity. Voltage-clamp studies presented in this paper indicate that the six different pyloric $I_{\mathrm{A}} \mathrm{s}$ more closely resemble lobster $I_{\text {shal }}$ than lobster $I_{\text {shaker }}$. To explicate this finding, we developed a quantitative, single-cell-reverse transcription PCR (SC-RT-PCR) method to count the number of shal transcripts in single, identified pyloric neurons. Using this method in conjunction with standard electrophysiological studies, we discovered a strictly linear relationship between shal transcript number and the size of the somatic $I_{\mathrm{A}}$ in all pyloric neurons. After considering all of our data, we believe that our earlier hypothesis was incorrect. Large variations in the ratio of somatic shaker to shal channels are not responsible for somatic $I_{\mathrm{A}}$ heterogeneity in the pyloric network.

\section{MATERIALS AND METHODS}

\section{Electrophysiology}

Pyloric neurons. The protocol used to study pyloric cell $I_{\mathrm{A}} \mathrm{s}$ using twoelectrode voltage clamp has been described in detail by Harris-Warrick et al. (1995a,b). Briefly, a stomatogastric ganglion with the appropriate motor nerves and the associated commissural and esophageal ganglia was dissected from the animal (Selverston et al., 1976) and pinned in a dish. The preparation was perfused continually at $16^{\circ} \mathrm{C}$ with lobster saline containing (in mM): $479 \mathrm{NaCl}, 12.8 \mathrm{KCl}, 13.7 \mathrm{CaCl}_{2}, 3.9 \mathrm{Na}_{2} \mathrm{SO}_{4}, 10$ $\mathrm{MgSO}_{4}, 2$ glucose, and 11.1 Tris, $\mathrm{pH}$ 7.35. Pyloric cells were identified electrophysiologically, using standard intracellular and extracellular recording techniques. $I_{\mathrm{A}} \mathrm{s}$ were characterized with a two-electrode voltage clamp. The following drugs were present in the saline to isolate the $I_{\mathrm{A}}$ and block synaptic transmission: $0.05 \mathrm{~mm}$ picrotoxin, $20 \mathrm{~mm}$ TEA,

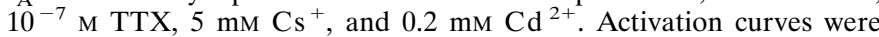
generated by holding each cell at a potential at which the $I_{\mathrm{A}}$ largely is inactivated and stepping to depolarized potentials to activate leaksubtracted non- $I_{\mathrm{A}}$ s. These non- $I_{\mathrm{A}}$ records were digitally subtracted from current traces in which the depolarization was preceded by a $200 \mathrm{msec}$ hyperpolarizing prestep to remove resting inactivation of $I_{\mathrm{A}}$. The resulting subtracted current could be abolished by $4 \mathrm{~mm} 4$-AP and represents pure $I_{\mathrm{A}}$. The inactivation data were generated by varying the amplitude of the prestep while stepping to a fixed, depolarized potential near full activation. In both cases the voltage-dependent peak currents were converted to conductance by using $E_{\mathrm{Rev}}=-86 \mathrm{mV}$ (Eisen and Marder, 1982 ). The average $E_{\mathrm{Rev}}$ was determined for each of the six pyloric cell types using tail current measurements of the $I_{\mathrm{A}}$. Tail currents were obtained by a series of hyperpolarizing steps after a 6 msec depolarization to $+20 \mathrm{mV}$ (preceded by a hyperpolarizing prepulse) to activate the $I_{\mathrm{A}}$. Non- $I_{\mathrm{A}} \mathrm{s}$ were digitally subtracted, as previously described. We found that the average $E_{\mathrm{Rev}}$ did not vary among the six pyloric cell types. Peak conductance was plotted versus the step potential for activation data or the prestep potential for inactivation data. The Boltzmann equation used for fitting was of the form:

$$
g_{\mathrm{A}}=G_{\max }\left(1 /\left(1+e^{-\left(V-V_{\mathrm{A}}\right) / s}\right)^{n}\right),
$$

where $G_{\max }$ is the maximal conductance, $V_{\mathrm{A}}$ is the voltage of halfmaximal activation, $s$ is the slope factor, and $n=3$ for activation and $n=$ 1 for inactivation. The inactivation kinetics were fit with two exponen- tials, using the least-squares minimization procedure of pClamp (Axon Instruments, Foster City, CA). The current as a function of time $(t)$ corresponds to the equation:

$$
I=I_{0}+I_{f} e^{-t / \tau_{f}}+I_{s} e^{-t / \tau_{s}}
$$

where $\tau_{f}$ and $\tau_{s}$ represent the time constants of inactivation, and the amplitude of each time constant, $I_{f}$ and $I_{s}$, represents the relative contribution of each component to the peak. The time constants of activation $\left(\tau_{a}\right)$ were estimated by fitting the entire waveform (as seen in Fig. 2) to Equation 2, using three exponentials, where $\tau_{f}, \tau_{s}, I_{f}$, and $I_{s}$ were fixed to the values obtained previously from the inactivation fits to that waveform, and $\tau_{a}$ and $I_{a}$ were allowed to vary. All time constants were determined for a depolarizing step to $+20 \mathrm{mV}$ (PD, PY, LP, and VD) or $+25 \mathrm{mV}$ (AB and IC)

The average cellular input capacitance for each of the six pyloric cell types was determined as previously described by Serrano and Getting (1989).

Xenopus oocytes. Two-electrode voltage clamp was used to study the shaker-evoked $I_{\mathrm{A}} 2-4 \mathrm{~d}$ after injecting an oocyte with shaker RNA [clone K17(I); M. Kim, D. Baro, C. Lanning, M. Doshi, J. Farnham, H. Moskowitz, J. Peck, B. Olivera, and R. Harris-Warrick, unpublished data]. Harvesting, injections, and maintenance of oocytes were as previously described (Baro et al., 1996a). Shaker currents (lobster $I_{\text {shaker }}$ ) were elicited by depolarizing steps from a holding potential of $-70 \mathrm{mV}$. Protocols and equations for determining the voltage dependence and inactivation kinetics of lobster $I_{\text {shaker }}$ were as described in Baro (1996a), except that a minimum of three exponentials was required to fit the lobster $I_{\text {shaker }}$ inactivation kinetics. A similar characterization of lobster $I_{\text {shal }}$ appeared in Baro et al. (1996a).

Derivation of the correction factor for $\mathrm{I}_{A} \mathrm{G}_{\text {max }}$

We have modeled the $I_{\mathrm{A}}$ as the sum of a current passing through two A-channels that differ only in their rates of inactivation (Harris-Warrick, 1995a,b; Willms, 1997). The peak conductance, $\bar{g}_{\mathrm{A}}$, is given by:

$$
\bar{g}_{\mathrm{A}}=\frac{I_{\mathrm{A}}}{V-E_{\mathrm{rev}}}=m^{\mathrm{p}}\left(\bar{g}_{f} h_{f}+\bar{g}_{s} h_{s}\right),
$$

where $V$ is the voltage, $E_{\text {rev }}$ is the reversal potential, $p$ is a positive integer, $\bar{g}_{f}$ and $\bar{g}_{s}$ are the maximal conductances of the populations of fast and slowly inactivating channels, respectively, $m$ is the activation variable, and $h_{f}$ and $h_{s}$ are the inactivation variables for the fast and slow channels, respectively. Thus, the peak conductance is determined by both the activation and inactivation variables.

Because of inactivation during the rising phase of the current, the peak conductance for an $I_{\mathrm{A}}$ is always less than the true maximal conductance (Fig. 1). We will define the true maximal conductance as the conductance obtained when all of the A-channels are open, before any inactivation occurs. An estimate of the true maximal conductance (called the corrected $G_{\max }$ ) can be obtained by multiplying the measured $G_{\max }$ by a correction factor that has been derived by Willms (1997). This correction factor $(\mathrm{CF})$ represents the ratio of the true maximal conductance to the measured peak maximal conductance and is given by:

$$
C F=\frac{\left(1+1 / p R_{\text {eff }}\right)^{p}}{p_{\mathrm{f}}\left(1+p R_{\mathrm{eff}}\right)^{-1 / R_{\mathrm{s}}}+p_{s}\left(1+p R_{\mathrm{eff}}\right)^{-1 / R_{s}}},
$$

where:

$$
p_{\mathrm{f}}=\frac{g_{f}}{g_{f}+g_{s}}
$$

and

$$
p_{s}=\frac{g_{s}}{g_{f}+g_{s}}
$$

are the fractions of the current that inactivate with the fast and slow time constants,

$$
R_{f}=\frac{\tau_{\text {fast }}}{\tau_{a}}
$$



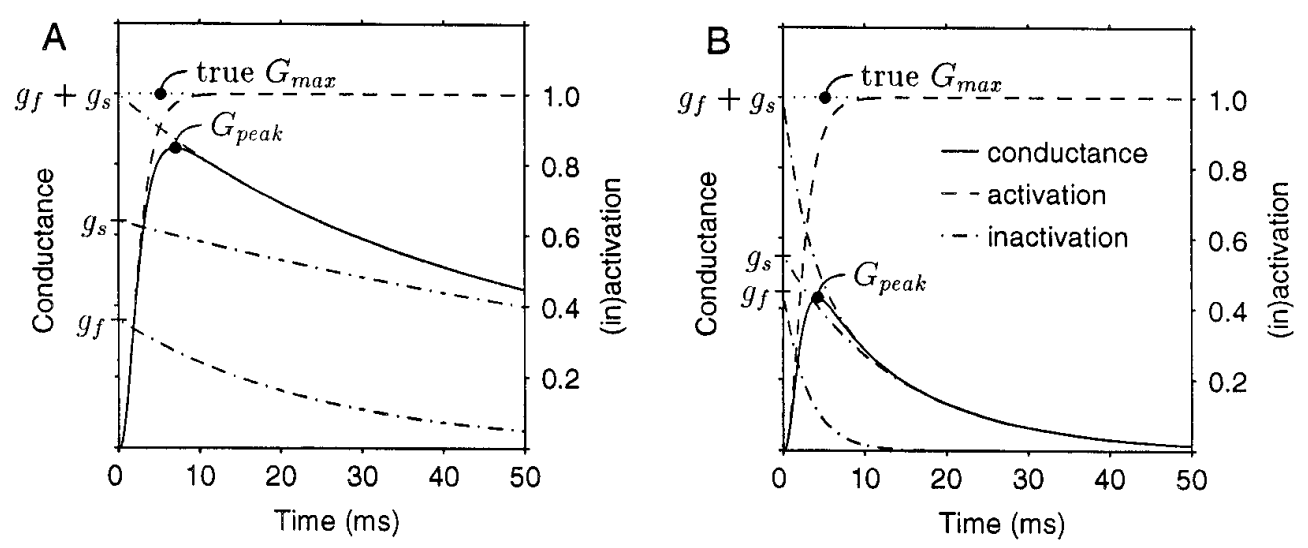

Figure 1. Theoretical conductance traces for a simulated voltage-clamp experiment starting from a strongly hyperpolarized state (fully deinactivated) and stepping to a strongly depolarized state (fully activated). The time constants of inactivation and the fraction of fast and slow channels were derived from Table 1 , using the parameters for the PD cell $(A)$ or the VD cell $(B)$. In both cases the activation time constant was 1.5 msec. Time courses for activation and inactivation are displayed also. The scale on the left ordinate is for the conductance (solid line), whereas the scale on the right ordinate is for the dimensionless activation and inactivation variables (dashed lines). The top inactivation curve is the sum of the two lower inactivation curves for the fast and slow channels. Note that the ratio of the peak conductance $\left(G_{\text {peak }}\right)$ to the true maximal conductance (true $G_{\max }$ ) is $\sim 85 \%$ for the PD cell and $43 \%$ for the VD cell.

$$
R_{s}=\frac{\tau_{\text {slow }}}{\tau_{a}}
$$

are the ratios of the inactivation time constants to the activation time constant, and the effective time ratio is given by:

$$
\frac{1}{R_{e f f}}=\frac{p_{f}}{R_{f}}+\frac{p_{s}}{R_{s}}
$$

When the relative number of A-channels in neurons with markedly different $I_{\mathrm{A}}$ inactivation rates is assessed, it is more appropriate to use the corrected $G_{\max }$, rather than the measured $G_{\max }$, because the corrected $G_{\max }$ accounts for differences in $I_{\mathrm{A}}$ inactivation kinetics, which the measured $G_{\max }$ does not. Simulated conductance traces based on our kinetic measurements of the PD and VD $I_{\mathrm{A}} \mathrm{s}$ are displayed in Figure 1 along with the time courses for activation and inactivation. The PD peak conductance (Fig. $1 A$ ) is much closer to the true $G_{\max }$ than the VD peak conductance (Fig. $1 B$ ), because the VD $I_{\mathrm{A}}$ inactivates much more rapidly than the PD $I_{\mathrm{A}}$ (Table 1; see Results). When multiplied by the correction factor, the peak conductances of both the $\mathrm{PD}$ and $\mathrm{VD} I_{\mathrm{A}} \mathrm{s}$ more closely approximate the true maximal conductance (Willms, 1997).

\section{Quantitative SC-RT-PCR}

Pyloric neurons were identified electrophysiologically, the glial caps were removed, and single neurons were isolated physically and used in shal RT-PCRs, as previously described (Baro et al., 1996b), with the following modifications. The $\alpha$-tubulin primers were excluded and an RNA standard was added to the RT master mix (see below). ${ }^{32} \mathrm{P}$ end-labeled primers (Baro et al., 1996b) were added to the PCR master mix $\left(10^{5}\right.$ $\mathrm{cpm} / 90 \mu \mathrm{l}$ of mix) and the $\left[\mathrm{MgCl}_{2}\right]$ was $1.5 \mathrm{~mm}$; the PCR cycle was $1 \times$ at $95^{\circ} \mathrm{C}$ for $5 \mathrm{~min} ; 25 \times$ at $94^{\circ} \mathrm{C}$ for $1 \mathrm{~min}, \rightarrow 68^{\circ} \mathrm{C}$ for $1 \mathrm{~min}, \rightarrow 72^{\circ} \mathrm{C}$ for $30 \mathrm{sec}$; and $5-10 \times$ at $94^{\circ} \mathrm{C}$ for $1.5 \mathrm{~min}, \rightarrow 68^{\circ} \mathrm{C}$ for $1 \mathrm{~min}, \rightarrow 72^{\circ} \mathrm{C}$ for 30 $\mathrm{sec}+10 \mathrm{sec}$ extension/cycle. The completed SC-RT-PCRs were electrophoresed on a $10 \%$ polyacrylamide gel. The gel was dried, and the PCR products were imaged with a PhosphorImager (Molecular Dynamics, Sunnyvale, CA) and stored on a Dell Dimension XPS 450V computer. The digitized ${ }^{32} \mathrm{P}$ signals were quantitated with ImageQuant software (version 3.3, Molecular Dynamics). The bands usually were positioned in the center of boxes (but see Results) for which the dimensions did not vary, and the relative amount of ${ }^{32} \mathrm{P}$ within each box was calculated automatically using a volume integration procedure.

The RNA standard was made by deleting a 45 bp segment (nucleotides 1282-1326) from the shal cDNA clone K/S10 (Baro et al., 1996a), using a modified, nested deletion method (Henikoff, 1987) in which the deletion extended bidirectionally from a BspEI restriction enzyme site. The deleted shal clone ( $\Delta$ shal) was linearized with HindIII in a standard restriction digest (Sambrook et al., 1989). The linearized $\Delta$ shal clone then served as a template in a transcription reaction using T3 RNA polymerase and a Ribomax kit (Promega, Madison, WI). The transcripts were DNased (Life Technologies, Gaithersburg, MD), a small amount of ${ }^{32} \mathrm{P}$-dCTP was added, and free nucleotides were removed with a Nuctrap column (Stratagene, La Jolla, CA). Fractions containing no radioactivity were phenol $/ \mathrm{CHCl}_{3}$ extracted immediately, ethanol precipitated, and resuspended in $\mathrm{dH}_{2} \mathrm{O}$. The concentration of the RNA standard was determined with a spectrophotometer. The concentration of the RNA standard was $\sim 10^{9}$-fold greater than the final concentration in a SC-RTPCR. Cloned DNA and RNase contamination were detected by using small aliquots of the concentrated RNA standard as the template in a PCR or in an overnight incubation in $1 \times$ superscript buffer at $37^{\circ} \mathrm{C}$, followed by denaturing gel electrophoresis. An RNA standard was used only if both DNA and RNase were absent and the RNA appeared as a discrete band of the appropriate size. The DNA- and RNase-free concentrated RNA standard was stored at $-70^{\circ} \mathrm{C}$ in $5 \mu \mathrm{l}$ aliquots in siliconized tubes for up to 1 year. One aliquot was used per experiment and then discarded. At the time of the experiment an aliquot of the RNA standard was diluted with $\mathrm{dH}_{2} \mathrm{O}$, using siliconized tubes to prevent the RNA from sticking. Carrier RNA (MS2, Boehringer Mannheim, Indianapolis, IN) also was added during the dilution series (final MS2: RNA standard $\left.=10^{6}, \mathrm{w} / \mathrm{w}\right)$. The diluted RNA standard was heated to $95^{\circ} \mathrm{C}$ for 5 min and quick-frozen on dry ice. The RNA standard was thawed, spun, and added to the RT master mix (which was stored immediately on ice) right before aliquotting the mix into the tubes containing the cells. Three different preparations of the sshal RNA standard were used in the quantitative SC-RT-PCR experiments described in this paper. All three preparations gave the same results.

\section{RESULTS}

\section{$I_{A}$ is unique in each pyloric cell type}

The 14 neurons of the pyloric network fall into six identified cell types (Fig. 2). Each cell type possesses a unique, unambiguous electrophysiological phenotype (Hartline and Graubard, 1992). To determine the extent of $I_{\mathrm{A}}$ heterogeneity in this network, we characterized the $I_{\mathrm{A}}$ in each cell type with two-electrode voltage clamp from the cell soma. Using this method, Hartline et al. (1993) demonstrated that the maximal amplitude, activation threshold, voltage dependence, and inactivation kinetics of the $I_{\mathrm{A}}$ were the same in an intact pyloric neuron as in a ligated soma. Thus, the $I_{\mathrm{A}} \mathrm{s}$ we measure from these intact neurons primarily reflect channels in the soma and initial length of the monopolar neurite, with little contribution from the current in unclamped distal neurites. We will refer to this current as the somatic $I_{\mathrm{A}}$.

Figure 2 demonstrates that the somatic $I_{\mathrm{A}}$ in each cell type is 


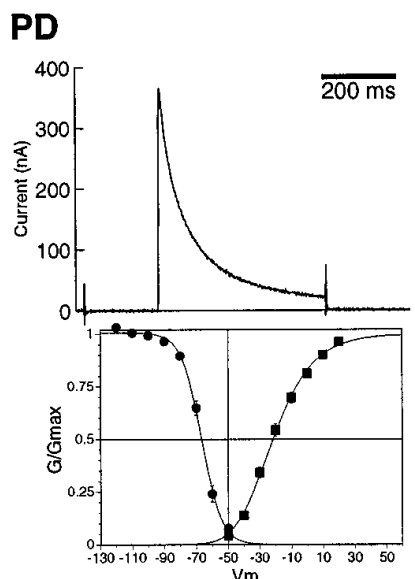

$A B$

Figure 2. The family of $I_{\mathrm{A}} \mathrm{s}$ in the pyloric network and the lobster shal and shaker currents. The six pyloric cell types and the number of cells in each cell type are $P D$, pyloric dilator (2); $L P$, lateral pyloric (1); $P Y$, pyloric constrictor (8); $A B$, anterior burster (1); $I C$, inferior cardiac (1); and $V D$, ventricular dilator (1). The top panel for each cell type illustrates the $I_{\mathrm{A}}$ waveform and amplitude activated by a depolarizing voltage step to $+20 \mathrm{mV}(P D, L P, P Y$, and $V D)$ or $+25 \mathrm{mV} \quad(A B$ and $I C)$. The A-conductances activated at these voltages experience a nearly identical driving force and are $>96 \%$ activated in $P D$, $P Y, I C$, and $V D$ and 72 and $82 \%$ activated in $L P$ and $A B$, respectively. Lobster $I_{\text {shal }}$ and lobster $I_{\text {shaker }}$ are voltageclamp recordings of Xenopus oocytes injected with either lobster shal or lobster shaker RNA. The bottom panel for each cell is the peak conductance/voltage relationship for activation (filled squares) and inactivation (filled circles) of the $I_{\mathrm{A}}$. The activation and inactivation curves are least-squares best fits to thirdand first-order Boltzmann equations, respectively. Each set of points is the average $\pm \mathrm{SEM}$ from $5(P D, A B, I C, V D), 7$ $(L P, P Y)$, or 17 (lobster $I_{\text {shaker }}$ ) cells. The lobster $I_{\text {shal }}$ curves were taken from Baro et al. (1996a). The steady-state $I_{\mathrm{A}}$ is the small window representing the subset of the area under both the activation and inactivation curves.

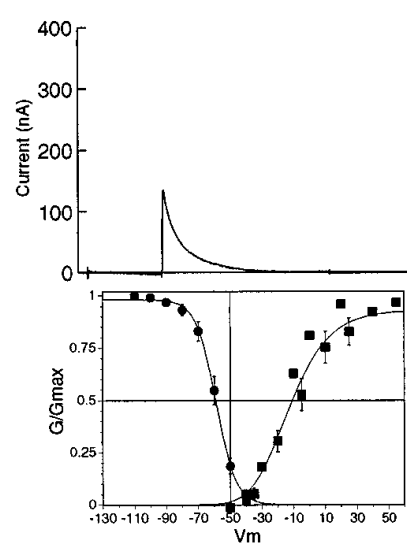

\section{Lobster Ishal}
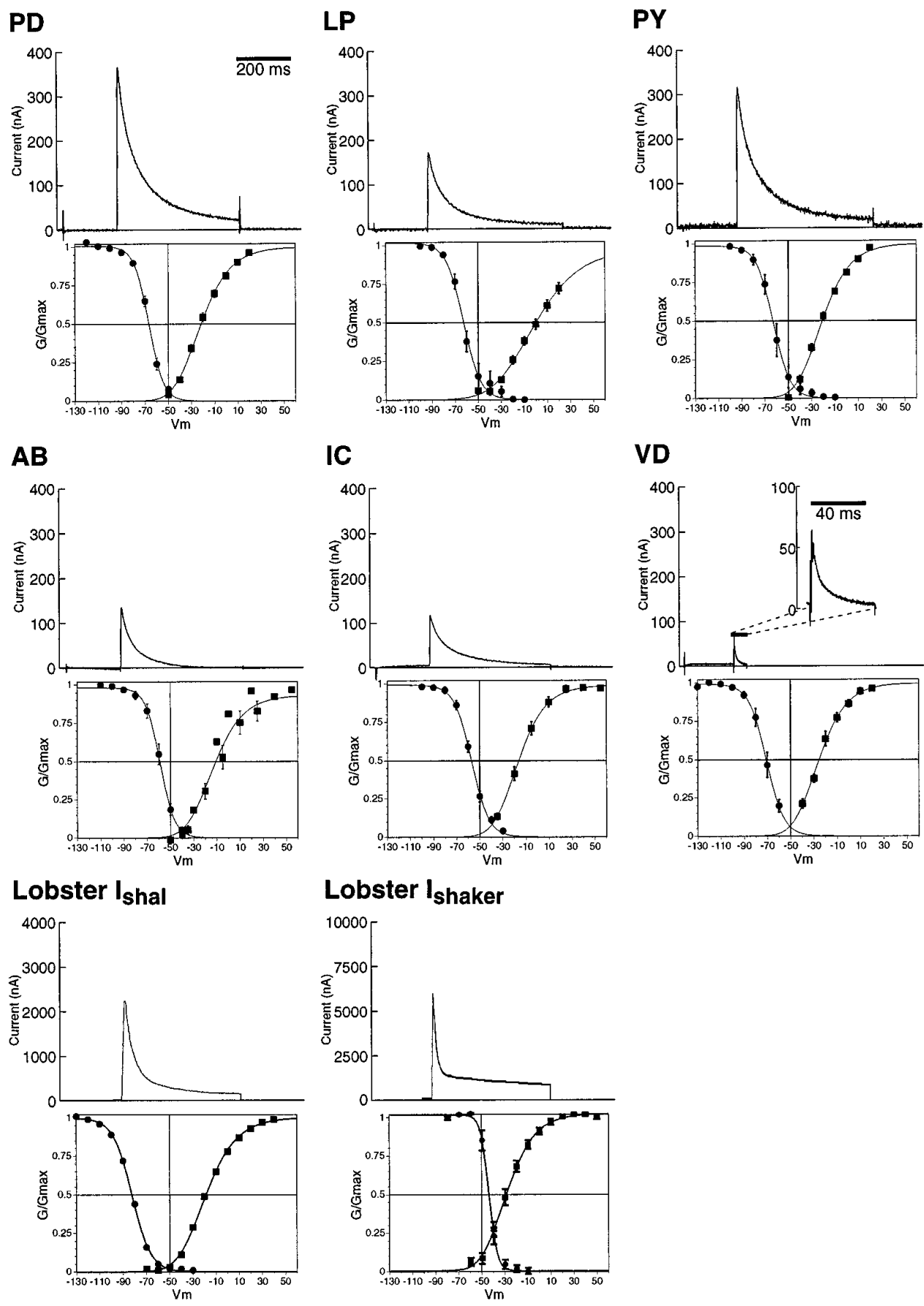

IC

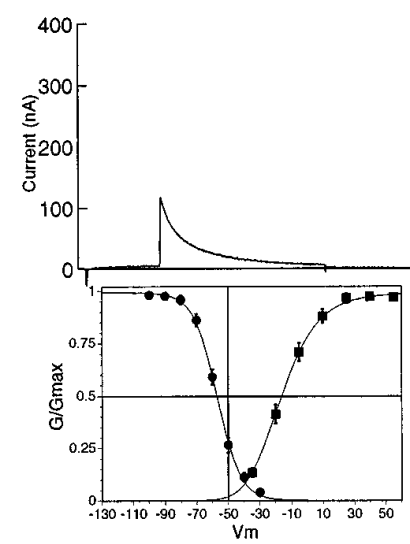

Lobster Ishaker

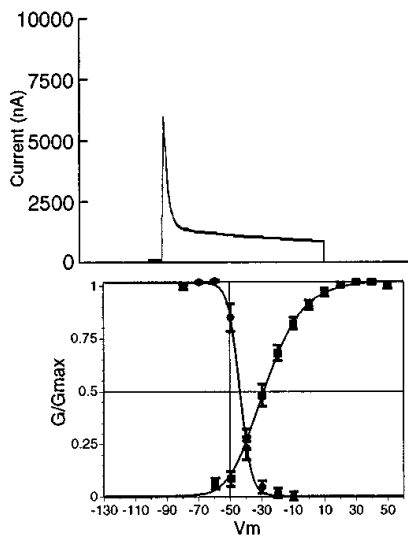

VD

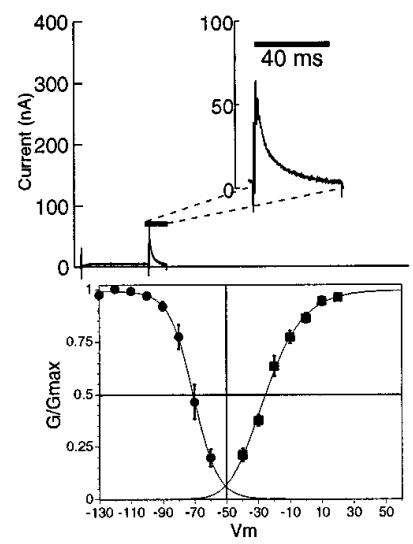

unique under the same recording conditions. The upper panels show the somatic $I_{\mathrm{A}} \mathrm{s}$ obtained by depolarizing pyloric cells to nearly the same membrane potential $(+20$ or $+25 \mathrm{mV})$. These traces demonstrate that at a given membrane potential both the size and the inactivation kinetics of $I_{\mathrm{A}}$ vary significantly between cell types. The peak amplitudes at these voltages vary by up to sevenfold. The $I_{\mathrm{A}}$ inactivation was fit by the sum of two exponentials. The $I_{\mathrm{A}} \mathrm{s}$ in the $\mathrm{VD}$ and $\mathrm{AB}$ cells inactivate much more rapidly relative to the other four cell types (Fig. 2, Table 1). This is attributable to two factors: (1) the time constants of inactivation $\left(\tau_{\text {fast }}\right.$ and $\left.\tau_{\text {slow }}\right)$ are up to 10-fold faster in these cells, and (2) a greater fraction of the channels inactivates with the fast, relative to the slow, time constant (Table 1). The lower panels in Figure
2 display the voltage dependence of the $I_{\mathrm{A}} \mathrm{s}$. The activation and inactivation curves are shifted in different cell types, with the $V_{1 / 2} \mathrm{~S}$ for activation and inactivation varying by up to $14 \mathrm{mV}$ (Table 1). Consequently, the steady-state "window" $I_{\mathrm{A}}$ is active over a different voltage range in different cells (Fig. 2). Finally, the maximal conductance $\left(G_{\max }\right)$, obtained from Boltzmann fits to the peak conductance/voltage relation, varies between cell types by a factor of eight (Table 1). All of these data indicate that the properties of the somatic $I_{\mathrm{A}}$ are distinct in each cell type under the same recording conditions. Because synaptic input is blocked by $\mathrm{Cd}^{2+}$ and picrotoxin and neuromodulators are not present in the bath, intrinsic differences in the baseline currents must be responsible for the observed $I_{\mathrm{A}}$ heterogeneity. 


\section{$I_{\text {A }}$ density varies significantly among pyloric neurons}

Cell-specific phenotypes can be brought about by changing the biophysical properties and/or the total amount of the $I_{\mathrm{A}}$ in a given cell type. Table 1 demonstrates that pyloric neurons differentially regulate the properties of the somatic $I_{\mathrm{A}}$. Next, we set out to determine whether the somatic $I_{\mathrm{A}}$ density also varies among cell types or whether the different current amplitudes seen in Figure 2 merely reflect the different sizes of pyloric neurons. To obtain the somatic $I_{\mathrm{A}}$ densities, we needed a measure of the size of both the soma and the maximal somatic $I_{\mathrm{A}}$ for each cell type. We estimated the average soma surface area for each cell type, using input capacitance as a gauge (Table 2). The average input capacitance for each cell type indicates that the sizes of pyloric somata vary considerably. If somatic $I_{\mathrm{A}}$ density is constant, then the maximum size of the somatic $I_{\mathrm{A}}$ should be positively correlated with soma size. Conversely, if the six pyloric cell types differentially regulate somatic $I_{\mathrm{A}}$ density, then the maximum size of the somatic $I_{\mathrm{A}}$ should vary in a manner that is independent of soma size. The $G_{\max }$, calculated from peak current measurements (Table 1), is used often as a measure of the size of the $I_{\mathrm{A}}$ in a cell. If we normalize the $G_{\max }$ for soma size (average $G_{\max }$ /average capacitance), somatic $I_{\mathrm{A}}$ density varies by a factor of 6.9 (Table 2).

The $G_{\max }$ values in Table 1 were derived from peak current measurements and thus underestimate the true maximum size of the $I_{\mathrm{A}}$ in a cell, because not all of the channels are open during the peak current because of channel inactivation during the rising phase of the current (Fig. 1, Materials and Methods). This is not a problem when neurons are compared with similar rates of $I_{\mathrm{A}}$ inactivation; however, if the $I_{\mathrm{A}}$ in one cell inactivates much more rapidly than the others, as is the case with $\mathrm{VD}$, the underestimate is disproportionately greater for that cell (Fig. 1). To compare more accurately the maximum size of the $I_{\mathrm{A}}$ among cell types, we multiplied the measured $G_{\max }$ by a correction factor (Willms, 1997) that represents the ratio of the maximal conductance before any inactivation occurs to the measured conductance at the peak current (see Materials and Methods). The resulting value, which we will term the corrected $G_{\text {max }}$, is shown in Table 2. The effect of the correction factor can be seen in Figure 3. In most cases the average corrected $G_{\max }$ is not significantly different from the average measured $G_{\max }$. However, the average corrected $G_{\text {max }}$ for the rapidly inactivating VD cell is more than twice the average measured $G_{\max }$.

Using the average corrected $G_{\max }$ as the measure of the maximum size of the somatic $I_{\mathrm{A}}$ in each cell type and normalizing for cell size (average corrected $G_{\max } /$ average capacitance), we find that the corrected somatic $I_{\mathrm{A}}$ density varies between cell types by up to a factor of 3.4 (Table 2). Therefore, with either the corrected or uncorrected $G_{\max }$, the size of the $I_{\mathrm{A}}$ does not simply increase or decrease with pyloric cell size. This finding is consistent with the idea that unique electrophysiological phenotypes are established by varying both the properties and the density of A-channels in a cell.

\section{Comparison of the pyloric cell $I_{\mathrm{A}} s$ to lobster $I_{\text {shal }}$ and lobster $I_{\text {shaker }}$}

Neurons could alter the properties and the amount of $I$ by differentially regulating A-channel gene expression. Like their Drosophila homologs, the Panulirus shaker and shal genes both encode $\alpha$-subunits for rapidly inactivating A-type channels, although with somewhat different properties than for the Drosophila channels (Fig. 2, Table 1; M. Kim et al., 1995, 1996; Baro et al., 1996a). We compared the $I_{\mathrm{A}} \mathrm{s}$ obtained from

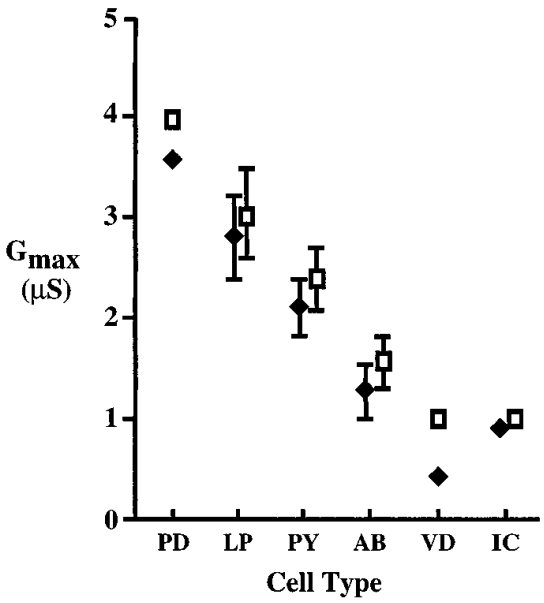

Figure 3. The effect of the correction factor varies among pyloric cell types. The measured average $G_{\max }$ (filled diamonds) and the corrected average $G_{\max }$ (open squares) are plotted for each of the six pyloric cell types. Error bars indicate the SEM when it is larger than the symbols. Note that the corrected $G_{\max }$ is approximately twice the measured $G_{\max }$ in the $V D$ cell, whereas the corrected and measured $G_{\max }$ do not vary greatly in the other cell types.

overexpressing shaker and shal cRNA in Xenopus oocytes (lobster $I_{\text {shaker }}$ and lobster $I_{\text {shal }}$ ) with the six pyloric $I_{\mathrm{A}} \mathrm{s}$ (Fig. 2, Table 1). We discovered that the variations in pyloric $I_{\mathrm{A}} \mathrm{s}$ were not consistent with the idea that distinct pyloric $I_{\mathrm{A}} \mathrm{S}$ result from different mixtures of shaker and shal A-channels. Instead, we found that the pyloric cell $I_{\mathrm{A}} \mathrm{s}$ qualitatively resemble lobster $I_{\text {shal }}$ more than lobster $I_{\text {shaker }}$; however, no pyloric $I_{\mathrm{A}}$ was identical in all parameters to lobster $I_{\text {shal }}$.

The voltage dependence of the six pyloric $I_{\mathrm{A}} \mathrm{s}$ was quite variable but generally resembled lobster $I_{\text {shal }}$ more than lobster $I_{\text {shaker }}$. The voltages of half activation $\left(V_{1 / 2 \text { act }}\right)$ for pyloric cell $I_{\mathrm{A}} \mathrm{s}$ range from -33 to $-45 \mathrm{mV}$. The lobster $I_{\text {shal }} V_{1 / 2 \text { act }}$ is approximately in the middle of this range $(-40 \mathrm{mV})$, whereas the lobster $I_{\text {shaker }} V_{1 / 2 \text { act }}$ lies below the lower limit of this range $(-46 \mathrm{mV})$. The slopes of the activation curves are similar for all $I_{\mathrm{A}} \mathrm{s}$ except the LP. The pyloric $I_{\mathrm{A}}$ voltages of half inactivation $\left(V_{1 / 2}\right.$ inact $)$ range from -71 to $-57 \mathrm{mV}$. The lobster $I_{\text {shal }} V_{1 / 2 \text { inact }}(-71 \mathrm{mV})$ is identical to the VD $I_{\mathrm{A}}$ and marks the lower bound of the range. In contrast, the lobster $I_{\text {shaker }} V_{1 / 2 \text { inact }}(-44 \mathrm{mV})$ is significantly more depolarized, and the slope of the inactivation curve is significantly steeper than any of the six pyloric $I_{\mathrm{A}} \mathrm{s}$. The pyloric $I_{\mathrm{A}}$ voltages of half activation and inactivation are not identical to either lobster $I_{\text {shal }}$ or lobster $I_{\text {shaker }}$, nor do they vary in a manner that would suggest the pyloric $I_{\mathrm{A}}$ is a mixture of lobster $I_{\text {shaker }}$ and lobster $I_{\text {shal }}$. For example, the $V_{1 / 2 \text { act }}$ of the VD $I_{\mathrm{A}}$ current is more similar to lobster $I_{\text {shaker }}$, whereas its $V_{1 / 2 \text { inact }}$ is identical to lobster $I_{\text {shal }}$.

The inactivation kinetics for all six pyloric $I_{\mathrm{A}} \mathrm{s}$ are also more similar to lobster $I_{\text {shal }}$ than lobster $I_{\text {shaker }}$ or a mixture of the two channel types. First, lobster $I_{\text {shal }}$ was fit with a double exponential relation, like all six pyloric $I_{\mathrm{A}} \mathrm{s}$, whereas lobster $I_{\text {shaker }}$ could be fit only with a third-order equation. Second, lobster $I_{\text {shaker }}$ contains a large noninactivating component that is not present in the six pyloric $I_{\mathrm{A}}$ s or lobster $I_{\text {shal }}$ (Fig. 2, Table 1). The fast time constants of inactivation $\left(\tau_{\text {fast }}\right)$ for the PD, PY, LP, and IC $I_{\mathrm{A}} \mathrm{s}$ are very similar to each other and to lobster $I_{\text {shal }}$, but they are significantly slower than lobster $I_{\text {shaker }}$. The slow time constants $\left(\tau_{\text {slow }}\right)$ of these pyloric neurons are approximately two times faster than 


\begin{tabular}{|c|c|c|c|c|c|c|}
\hline $\begin{array}{l}\text { Cell type } \\
\text { (number/type) }\end{array}$ & Inact $\tau_{\text {fast }}(\mathrm{msec})^{a}$ & Inact $\tau_{\text {slow }}(\mathrm{msec})^{a}$ & $\begin{array}{l}\text { Inact } \tau_{\text {slow } 2} \\
(\mathrm{msec})^{a, 9}\end{array}$ & $\%$ peak $I_{\mathrm{A}}\left(\tau_{\text {fast }}\right)^{a}$ & $\%$ peak $I_{\mathrm{A}}\left(\tau_{\text {slow }}\right)^{a}$ & $\begin{array}{l}(\%) \text { peak } I_{\mathrm{A}} \\
\left(\tau_{\text {slow } 2}\right)^{a, 9}\end{array}$ \\
\hline PD (2) & $\begin{array}{l}25^{5,6} \pm 3 \\
n=5\end{array}$ & $\begin{array}{l}106^{6} \pm 11 \\
n=5\end{array}$ & NA & $\begin{array}{l}0.36 \pm 0.01 \\
n=5\end{array}$ & $\begin{array}{l}0.64 \pm 0.01 \\
n=5\end{array}$ & NA \\
\hline LP (1) & $\begin{array}{l}27^{5,6} \pm 2 \\
n=7\end{array}$ & $\begin{array}{l}106^{6} \pm 11 \\
n=7\end{array}$ & NA & $\begin{array}{l}0.35 \pm 0.05 \\
n=7\end{array}$ & $\begin{array}{l}0.65 \pm 0.04 \\
n=7\end{array}$ & NA \\
\hline PY (8) & $\begin{array}{l}25^{5,6} \pm 3 \\
n=7\end{array}$ & $\begin{array}{l}113^{5,6} \pm 24 \\
n=7\end{array}$ & NA & $\begin{array}{l}0.39 \pm 0.04 \\
n=7\end{array}$ & $\begin{array}{l}0.61 \pm 0.04 \\
n=7\end{array}$ & NA \\
\hline $\mathrm{AB}(1)$ & $\begin{array}{c}16^{2,3,4,6,7} \pm 1 \\
n=5\end{array}$ & $\begin{array}{l}75^{4,6,7} \pm 12 \\
n=5\end{array}$ & NA & $\begin{array}{l}0.44 \pm 0.05 \\
n=5\end{array}$ & $\begin{array}{l}0.56 \pm 0.05 \\
n=5\end{array}$ & NA \\
\hline VD (1) & $\begin{array}{l}3^{2,3,4,5,7} \pm 0.4 \\
n=5\end{array}$ & $\begin{array}{c}14^{2,3,4,5,7} \pm 3 \\
n=5\end{array}$ & NA & $\begin{array}{l}0.45 \pm 0.05 \\
n=5\end{array}$ & $\begin{array}{l}0.55 \pm 0.05 \\
n=5\end{array}$ & NA \\
\hline IC (1) & $\begin{array}{l}29^{5,6} \pm 2 \\
n=5\end{array}$ & $\begin{array}{l}136^{5,6} \pm 15 \\
n=5\end{array}$ & NA & $\begin{array}{l}0.34 \pm 0.08 \\
n=5\end{array}$ & $\begin{array}{l}0.66 \pm 0.08 \\
n=5\end{array}$ & NA \\
\hline Lobster $^{1} I_{\text {shal }}$ & $\begin{array}{c}31^{2,4,5,6} \pm 1 \\
n=16\end{array}$ & $\begin{array}{c}220^{2,3,4,5,6,7} \pm 7 \\
n=16\end{array}$ & NA & $\begin{array}{c}0.78^{2,3,4,5,6,7} \pm 0.01 \\
n=16\end{array}$ & $\begin{array}{c}0.22^{2,3,4,5,6,7} \pm 0.01 \\
n=16\end{array}$ & NA \\
\hline Lobster ${ }^{10} I_{\text {shaker }}$ & $\begin{array}{c}13^{2,3,4,5,6,7,8} \pm 0.3 \\
n=16\end{array}$ & $\begin{array}{c}535^{2,3,4,5,6,7,8} \pm 26 \\
n=16\end{array}$ & $\begin{array}{c}1834 \pm 51 \\
n=16\end{array}$ & $\begin{array}{c}0.50^{2,3,4,5,6,7,8} \pm 0.09 \\
n=16\end{array}$ & $\begin{array}{c}0.1^{2,3,4,5,6,7,8} \pm 0.8 \\
n=16\end{array}$ & $\begin{array}{c}0.25 \pm 0.9 \\
n=16\end{array}$ \\
\hline
\end{tabular}

Values indicate averages \pm SEM.

${ }^{1} \mathrm{~A}$ description of how these parameters were obtained can be found in Baro et al. (1996a).

Significantly different $(p<0.05)$ from ${ }^{2} \mathrm{PD},{ }^{3} \mathrm{LP},{ }^{4} \mathrm{PY},{ }^{5} \mathrm{AB},{ }^{6} \mathrm{VD},{ }^{7} \mathrm{IC},{ }^{8} I_{\text {shal }}$.

${ }^{9}$ Significant differences not determined.

${ }^{10} 15 \%$ of the current was noninactivating.

${ }^{a}$ Obtained from Equation 2 in Materials and Methods.

${ }^{b}$ Obtained from Equation 1 in Materials and Methods.

lobster $I_{\text {shal }}$, but 5-17 times faster than lobster $I_{\text {shaker }}$ (Table 1). The time constants of inactivation for the $\mathrm{AB}$ and $\mathrm{VD} I_{\mathrm{A}} \mathrm{s}$ are significantly different from both lobster $I_{\text {shal }}$ and lobster $I_{\text {shaker }}$ (Fig. 2, Table 1).

A comparison of the eight different $I_{\mathrm{A}}$ s shown in Figure 2 and Table 1 is not sufficient to ascertain which A-channels carry the pyloric $I_{\mathrm{A}} \mathrm{s}$. However, the overall similarity of the neuronal $I_{\mathrm{A}} \mathrm{s}$ to lobster $I_{\text {shal }}$ suggested that shal may be an important contributor to the pyloric cell $I_{\mathrm{A}} \mathrm{s}$. Therefore, we developed a method to quantitate shal gene expression in single identified neurons, using noncompetitive RT-PCR (Ferre, 1992; Foley et al., 1993; Gause and Adamovicz, 1994; Sucher and Deitcher, 1995).

\section{Quantitating shal gene expression in single identified neurons}

In our method, RNA from a single cell is reverse-transcribed and amplified along with $10^{3}$ sshal RNA standard molecules in an RT-PCR containing ${ }^{32} \mathrm{P}$-labeled Panulirus shal-specific primers. The $\Delta$ shal RNA standard is identical to the endogenous shal transcript, except that it lacks the distal-most portions of the $5^{\prime}$ and $3^{\prime}$ untranslated regions and it contains a very small deletion in the region between the two PCR primers. This minor deletion allows the separation of the cellular shal and the standard $\Delta$ shal RT-PCR products on the basis of size. The number of cellular transcripts is determined by normalizing the cellular shal RTPCR product against the standard $\Delta$ shal RT-PCR product.

The results of a typical experiment are shown in Figure 4. Neurons were identified electrophysiologically. Glial caps were removed because the shal gene is expressed in glial cells (Baro et al., 1996b), and individual neurons were physically isolated and used in RT-PCRs containing $10^{3} \Delta$ shal RNA standard molecules. The RT-PCR products were size-separated, using polyacrylamide gel electrophoresis, and phosphorimaged. The upper band in each lane represents the product of the endogenous shal tran- scripts present in a single cell. The lower band represents the product of the $1000 \Delta$ shal RNA standard molecules. The number of shal transcripts in each cell was calculated from:

$$
\left(\frac{\mathrm{cpm} \text { in shal band }}{\mathrm{cpm} \text { in } \Delta \text { shal band }}\right)\left(10^{3}\right)\left(X^{n}\right),
$$

where $X$ is the relative amplification efficiency per cycle of a $\Delta$ shal to a shal DNA template, and $n$ is the number of cycles in the PCR.

Shorter DNA molecules often are amplified more efficiently than longer molecules in a PCR. To determine whether the 262 bp $\Delta$ shal PCR product was amplified more efficiently than the 307 bp shal PCR product, we added equal numbers of shal and $\Delta$ shal DNA templates to the same PCR (Fig. 5). The PCR products were electrophoresed and phosphorimaged, and the digitized ${ }^{32} \mathrm{P}$ signals were quantitated as described in Materials and Methods. The amplification efficiency per cycle of a $\Delta$ shal relative to a shal DNA template was determined from the following equation: $X=$ $(\mathrm{cpm} \Delta \text { shal } / \mathrm{cpm} \text { shal })^{1 / n}$, where $X$ and $n$ are described above. We found that $\Delta$ shal DNA molecules are amplified on average $1.029 \pm 0.002(n=103)$ times more efficiently than an equivalent

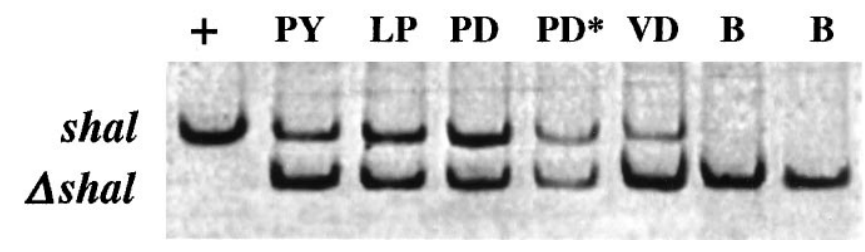

Figure 4. Results from a typical SC-RT-PCR experiment. Each lane represents one SC-RT-PCR. The template in each SC-RT-PCR was cloned shal DNA (+), 1000 sshal RNA standard molecules (B), or 1000 $\Delta$ shal RNA standard molecules plus a single identified neuron lacking a glial cap $\left(P Y, L P, P D, P D^{*}\right.$, and $\left.V D\right)$. Data from the cell $P D^{*}$ were not used because of obvious RNase degradation (see Results). 
Table 1. Continued

\begin{tabular}{|c|c|c|c|c|}
\hline Act $V_{1 / 2}(\mathrm{mV})^{b}$ & Act slope factor $(\mathrm{mV})^{b}$ & Inact $V_{1 / 2}(\mathrm{mV})^{b}$ & Inact slope factor $(\mathrm{mV})^{b}$ & $G_{\max }(\mu \mathrm{S})^{9}$ \\
\hline$-42^{3,5,7} \pm 1$ & $15^{3} \pm 0.7$ & $-67^{5,7} \pm 1$ & $6 \pm 0.3$ & $3.55 \pm 0.11$ \\
\hline$n=5$ & $n=5$ & $n=5$ & $n=5$ & $n=5$ \\
\hline$-33^{2,4,6,7} \pm 1.5$ & $25^{2,4,5,6,7} \pm 1.4$ & $-63^{6,7} \pm 1.4$ & $8 \pm 2.9$ & $2.79 \pm 0.41$ \\
\hline$n=8$ & $n=7$ & $n=3$ & $n=3$ & $n=7$ \\
\hline$-40^{3,5,6,7} \pm 1.5$ & $14^{3,5} \pm 0.4$ & $-63^{6,7} \pm 2.7$ & $7 \pm 0.9$ & $2.09 \pm 0.27$ \\
\hline$n=8$ & $n=7$ & $n=6$ & $n=6$ & $n=7$ \\
\hline$-33^{2,4,6,7} \pm 2$ & $15^{3,4} \pm 2$ & $-60^{2,6} \pm 1.4$ & $6 \pm 0.5$ & $1.27 \pm 0.27$ \\
\hline$n=5$ & $n=5$ & $n=5$ & $n=5$ & $n=7$ \\
\hline$-45^{3,4,5,7} \pm 2.2$ & $14^{3} \pm 1.6$ & $-71^{3,4,5,7} \pm 2$ & $7 \pm 0.5$ & $0.44 \pm 0.05$ \\
\hline$n=5$ & $n=5$ & $n=5$ & $n=5$ & $n=5$ \\
\hline$-36^{2,3,4,5,6} \pm 1.2$ & $14^{3} \pm 1.4$ & $-57^{2,3,4,6} \pm 1.2$ & $7 \pm 0.6$ & $0.89 \pm 0.08$ \\
\hline$n=5$ & $n=5$ & $n=5$ & $n=5$ & $n=5$ \\
\hline$-40^{3,5,6,7} \pm 0.4$ & $15^{3} \pm 0.4$ & $-71^{2,3,4,5,7} \pm 0.7$ & $5 \pm 0.2$ & NA \\
\hline$n=16$ & $n=16$ & $n=16$ & $n=16$ & \\
\hline$-46^{2,3,4,5,7,8} \pm 0.7$ & $14^{2,3,5,8} \pm 0.3$ & $-44^{2,3,4,5,6,7,8} \pm 0.4$ & $3^{2,3,4,5,6,7,8} \pm 0.1$ & NA \\
\hline$n=16$ & $n=16$ & $n=16$ & $n=16$ & \\
\hline
\end{tabular}

number of shal DNA molecules per PCR cycle. So, for a 30-cycle PCR, $X^{n}=(1.029)^{30}=2.4$.

To ensure that our measurements of the relative amplification efficiency were accurate, we used several different DNA template preparations, and we varied the number of starting molecules and PCR cycles within the linear range of amplification (see below); otherwise, the conditions of the PCR were identical to the quantitative SC-RT-PCR. In those experiments with a large number of template molecules and PCR cycles, the shal and $\Delta$ shal products tended to bleed together along the edges of the lane (Fig. $5 C$ ). Because the bands "smile" (Figs. 4-6), a smeared/streaked signal along the edge of the lane belongs to the band just below the smear/streak. Thus, in the few cases in which bleeding occurred, the phosphorimager measuring boxes (see Materials and Methods) were positioned so that the smear/streak between the bands went with the lower band. The average amplification efficiency of $\Delta$ shal relative to shal did not vary significantly with the number of starting molecules or PCR cycles.

RNase is the bane of the quantitative SC-RT-PCR experiments. If an RNase is introduced when the cellular transcripts and the RNA standard are both present, they should be degraded equally, and the ratio of the signals will not change, just their intensity. However, if an RNase acts preferentially on either the endogenous transcript or the standard, there will be

Table 2. Somatic $\mathrm{I}_{\mathrm{A}}$ and shal transcript density in pyloric cells

\begin{tabular}{|c|c|c|c|c|c|}
\hline $\begin{array}{l}\text { Cell type } \\
\text { (number/type) }\end{array}$ & $\begin{array}{l}\text { Input capacitance } \\
(\mathrm{nF})\end{array}$ & $\begin{array}{l}I_{\mathrm{A}} \text { density }^{8} \\
(\mu \mathrm{S} / \mathrm{nF})\end{array}$ & $\begin{array}{l}\text { Corrected } G_{\max }^{1} \\
(\mu \mathrm{S})\end{array}$ & $\begin{array}{l}\text { Corrected } I_{\mathrm{A}} \text { density }^{9} \\
(\mu \mathrm{S} / \mathrm{nF})\end{array}$ & $\begin{array}{l}\text { shal transcript density }{ }^{10} \\
\text { (transcripts/nF) }\end{array}$ \\
\hline $\mathrm{PD}(2)$ & $\begin{array}{c}1.2^{4,5,6,7} \pm 0.07 \\
n=10\end{array}$ & 2.96 & $\begin{array}{c}3.98^{3,4,5,6,7} \pm 0.12 \\
n=5\end{array}$ & 3.32 & 2200 \\
\hline LP (1) & $\begin{array}{c}1.47^{4,5,6} \pm 0.2 \\
n=7\end{array}$ & 1.9 & $\begin{array}{c}3.05^{2,5,6,7} \pm 0.47 \\
n=7\end{array}$ & 2.07 & 1544 \\
\hline PY (8) & $\begin{array}{c}0.9^{2,3} \pm 0.08 \\
n=10\end{array}$ & 2.32 & $\begin{array}{l}2.39^{2,6,7} \pm 0.34 \\
n=7\end{array}$ & 2.66 & 1878 \\
\hline $\mathrm{AB}(1)$ & $\begin{array}{c}0.66^{2,3,6} \pm 0.08 \\
n=3\end{array}$ & 1.92 & $\begin{array}{l}1.57^{2,3} \pm 0.28 \\
n=5\end{array}$ & 2.38 & 1742 \\
\hline VD (1) & $\begin{array}{c}1.02^{2,3,5} \pm 0.03 \\
n=5\end{array}$ & 0.43 & $\begin{array}{l}1.00^{2,3,4} \pm 0.14 \\
n=5\end{array}$ & 0.98 & 1049 \\
\hline IC (1) & $\begin{array}{c}0.87^{2} \pm 0.14 \\
n=3\end{array}$ & 1.02 & $\begin{array}{l}0.98^{2,3,4} \pm 0.09 \\
n=5\end{array}$ & 1.13 & 1092 \\
\hline
\end{tabular}

Values indicate averages \pm SEM.

${ }^{1}$ The corrected $G_{\max }=G_{\max } \times$ correction factor (see Materials and Methods).

Significantly different $(p<0.05)$ from ${ }^{2} \mathrm{PD},{ }^{3} \mathrm{LP},{ }^{4} \mathrm{PY},{ }^{5} \mathrm{AB},{ }^{6} \mathrm{VD},{ }^{7} \mathrm{IC}$.

${ }^{8} I_{\mathrm{A}}$ density $=$ average $G_{\max } \div$ average capacitance.

${ }^{9}$ Corrected $I_{\mathrm{A}}$ density $=$ average corrected $G_{\max } \div$ average capacitance (see Materials and Methods).

${ }^{10}$ shal transcript density $=$ average number of shal transcripts $\div$ average capacitance. 


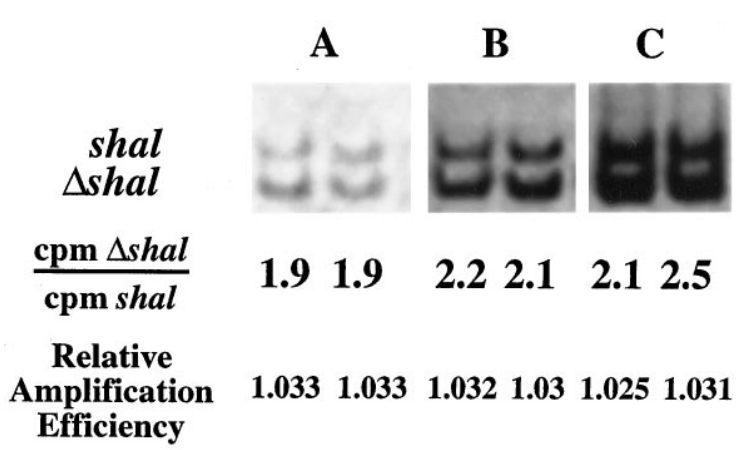

Figure 5. The relative amplification efficiency of $\Delta$ shal over shal. Six representative PCRs are shown. Equal numbers of $\Delta$ shal and shal DNA molecules were added to each PCR. PCRs were performed for $(A)$ $20,(B) 25$, or $(C) 30$ cycles. The PCR products were electrophoresed and phosphorimaged, and the digitized ${ }^{32} \mathrm{P}$ signals were quantitated. The amplification efficiency per cycle of a $\Delta$ shal relative to a shal DNA template was determined from the following equation: $X=(\mathrm{cpm} \Delta$ shal/ cpm shal $)^{1 / n}$, where $X$ is the relative amplification efficiency per cycle and $n$ is the number of cycles.

errors in our measurement. To detect and control for trace RNase contamination, we carried at least two blanks per experiment (RT-PCRs containing $1000 \Delta$ shal RNA standard molecules but no cell; Fig. 4). We used the data from an experiment only if the counts per minute in the standard bands of the blanks varied by less than a factor of 2 . We used the data from an individual cell within an experiment only if the counts per minute in the standard band of that SC-RT-PCR were within or above the range of the blanks. For example, in Figure 4 the starred PD cell failed this criterion, so the data from this cell were not used.

\section{Demonstrating that input is proportional to output in our SC-RT-PCRs}

For our SC-RT-PCR method to be quantitative, we have to demonstrate that input is proportional to output. In a typical PCR the product increases exponentially with cycle number until eventually a plateau is reached. The PCR product is proportional to the number of starting molecules only if the PCR remains within the exponential phase (for review, see Ferre, 1992; Foley et al., 1993; Gause and Adamovicz, 1994). Several factors determine when the plateau is reached, including the number of starting molecules: everything else being equal, the larger the number of starting molecules, the sooner the PCR enters the plateau phase. For a given cycle number the linear range of amplification is defined as the range of starting template molecules over which the PCR remains within the exponential phase (for review, see Ferre, 1992). We determined the linear range of amplification for a 35 cycle RT-PCR under our quantitative SC-RT-PCR conditions (Fig. 6). RT-PCRs containing 50-50,000 $\Delta$ shal RNA molecules were performed for 35 cycles, and the amount of ${ }^{32} \mathrm{P}$ incorporated into the $\Delta$ shal RT-PCR product was quantitated (Fig. $6 A$ ). Figure $6 B$ shows the relationship between the number of starting molecules and the amount of product. Each data point represents the average of nine different RT-PCR experiments. As Figure $6 B$ demonstrates, the $\log$ of the product increases linearly as a function of the log of the starting template over the range from 50 to at least 10,000 $\Delta$ shal RNA molecules. The data point at 50,000 molecules is slightly below the line. This suggests that an RT-PCR containing 50,000 $\Delta$ shal starting molecules enters the beginning

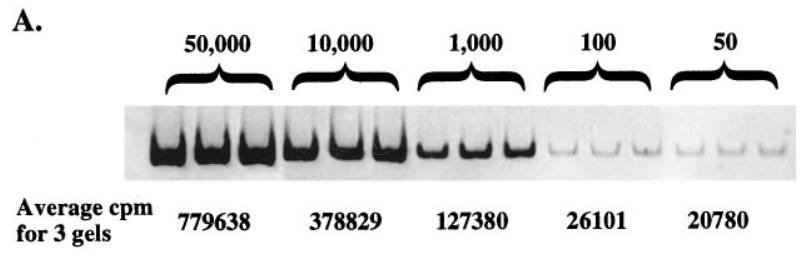

B.

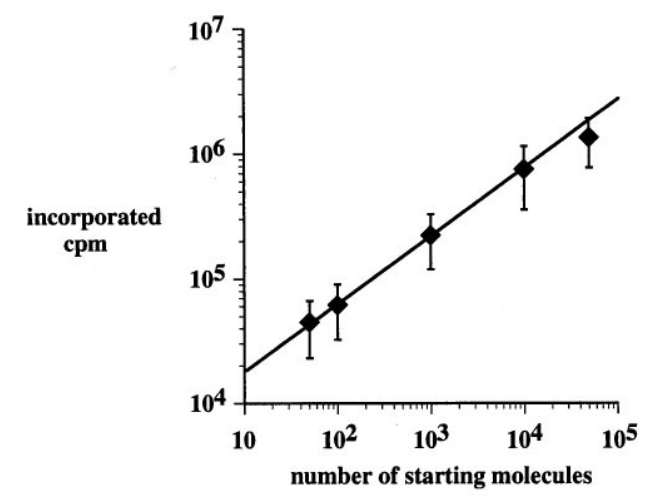

Figure 6. Determining the linear range of amplification. $A$, Fifteen shal RT-PCRs were performed for 35 cycles. The templates in each of three RT-PCRs were $5 \times 10^{4}, 10^{4}, 10^{3}, 10^{2}$, or $50 \Delta$ shal RNA molecules. Ten microliters of the completed RT-PCRs were run on each of three gels (only one gel is shown) and phosphorimaged. The average incorporated counts per minute in the nine resulting bands were determined for each of the five templates. $B$, The experiment in $A$ was repeated three times, and the average incorporated counts per minute for the five templates were determined. The average incorporated counts per minute were plotted against the number of starting molecules on a $\log / \log$ scale. The error bars represent the SEM. The line represents a linear regression to the first four data points (from 50 to $10^{4}$ molecules).

stages of the plateau phase by 35 cycles and input may no longer be proportional to output. However, when the RT-PCR contains fewer starting molecules, and in particular $<10^{4}$, input is still proportional to output after 35 cycles. Thus, the linear range of amplification for a 35 cycle RT-PCR under the present SC-RTPCR conditions includes at least 50-10,000 sshal RNA template molecules. Preliminary experiments indicated that the number of endogenous shal transcripts in a pyloric neuron never exceeded 4000. Because we add 1000 sshal RNA standard molecules to a SC-RT-PCR, each reaction has between 1000 and 5000 starting molecules, which is well within the linear range of amplification for a 35 cycle SC-RT-PCR (Fig. $6 B$ ). In some experiments we reduced the SC-RT-PCR cycle number to 30 , and this did not change our results. This is what we would predict, because the upper limit of the linear range of amplification increases with decreasing cycle number. We should point out that the level of nonspecific RNA does not change significantly when a cell is added to the RT-PCR, because we include $20 \mathrm{ng}$ of carrier RNA in each RT-PCR and a neuron most likely contributes $<100 \mathrm{pg}$ of nonspecific RNA to a reaction. Thus, adding a cell to the RTPCR will not affect the linear range of amplification [see Gause and Adamovicz (1994) for a discussion of this point].

\section{shal transcript number varies significantly among cell types}

We performed a number of SC-RT-PCR experiments to determine the average number of shal transcripts in each pyloric cell type. The mean number of shal transcripts is plotted for each cell type in Figure 7. There are several points to be made. First, all 


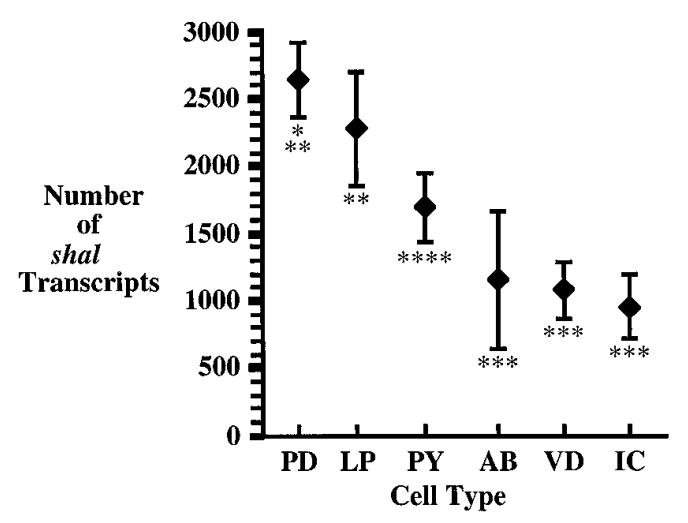

Figure 7. The average number of shal transcripts varies significantly among pyloric cell types. The average number of shal transcripts is plotted for each cell type; the error bars represent the SEM. The number of cells examined in each cell type was $P D, 9 ; L P, 6 ; P Y, 14 ; A B, 4 ; V D, 9$; and $I C$, 6. Asterisks represent significant difference $(p<0.05)$ : PY (*); AB, VD, $\mathrm{IC}(* *) ; \mathrm{PD}, \mathrm{LP}(* * *) ; \mathrm{PD}(* * * *)$.

pyloric cells express shal. Second, the number of shal transcripts within a given cell type was consistent between individuals. Third, we observed significant differences in the average number of shal transcripts among cell types, with shal transcript levels varying by a factor of 2.8. Fourth, there is no positive correlation between the average number of shal transcripts and the average input capacitance for a given cell type, as seen by our calculations of the shal transcript density, which varied from cell type to cell type (Table 2). Thus, pyloric cells differentially regulate shal gene expression at the level of the transcript. Pyloric neurons may differentially modulate transcript levels by varying rates of transcription, transcript processing, and/or transcript turnover. The fact that transcript levels are regulated does not exclude additional translational and post-translational regulation of shal gene expression in pyloric neurons as well.

The maximum size of the somatic $I_{A}$ varies as a linear function of shal gene expression

If shal underlies a major fraction of the somatic $I_{\mathrm{A}}$ in pyloric neurons, then it might be possible to correlate the maximum size of the somatic $I_{\mathrm{A}}$ with the number of shal transcripts in a given pyloric cell type. Plotting the mean number of shal transcripts in each cell type versus the average measured $G_{\max }$ reveals a remarkably strong positive correlation (Fig. 8A). A linear regression fit to these data has an $R^{2}$ value of 0.95 , demonstrating that the maximum size of the somatic $I_{\mathrm{A}}$ in each cell type varies as a linear function of shal transcript levels $(p<0.001)$. The VD data point is significantly below the line in Figure $8 A$. We suggest this is attributable to an underestimate of the $\mathrm{VD} G_{\max }$ calculated from peak current measurements because of the more rapid inactivation of the $\mathrm{VD} I_{\mathrm{A}}$ relative to other pyloric neurons (see Fig. 1). As described above, we can compensate for this underestimate by plotting the corrected $G_{\max }$ versus shal transcript number for each cell type (Fig. $8 B$ ). In this case the VD more closely approximates the line so that $R^{2}$ becomes 0.98 and $p<$ 0.0002 .

The simplest interpretation of our data is that shal is an $\alpha$-subunit for the majority of somatic A-channels in all 14 neurons of the pyloric network. Research on flies and mammals has shown that $\mathrm{K}^{+}$channel $\alpha$-subunits from the shaker and shal subfamilies cannot coassemble to form a heteromeric channel, and one never finds an A-channel composed of shaker and shal $\alpha$-subunits (Co-
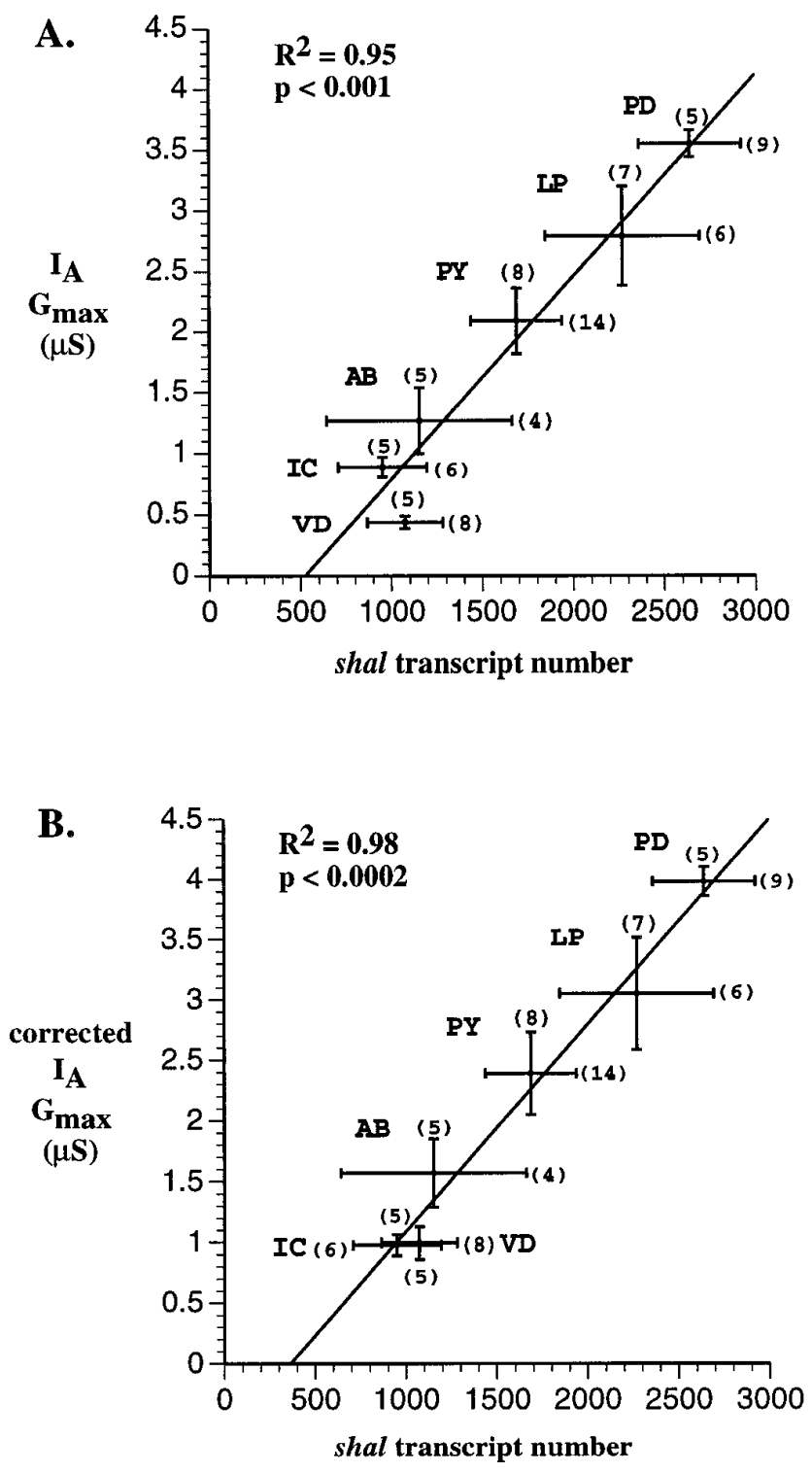

Figure 8. The maximum size of the somatic $I_{\mathrm{A}}$ varies as a function of shal gene expression. The average uncorrected $(A)$ or corrected $(B) G_{\max }$ was plotted against the mean number of shal transcripts for each of the six pyloric cell types. The lines represent linear regressions of the data points. The error bars on each data point represent the SE. The numbers in parentheses represent the number of cells used to measure either the $G_{\max }$ or the number of shal transcripts.

varrubias et al., 1991; Li et al., 1992; Sheng et al., 1993; Wang et al., 1993; Deal et al., 1994; Lee et al., 1994; Shen et al., 1995; Xu et al., 1995) (but see Shahidullah et al., 1996). Subfamily-specific assembly is mediated via the NAB domain in the N-terminal regions of $\mathrm{K}^{+}$channel subunits (Xu et al., 1995). NAB domains are conserved in a subfamily-specific manner. The amino acid identity among different NAB regions within a subfamily is generally $>70 \%$, but between subfamilies NAB identity drops to $\sim 30 \%$ (Xu et al., 1995). Because the NAB domains of Panulirus shaker and shal are 94 and $97 \%$ identical to their Drosophila homologs, respectively, we believe that Panulirus shaker and shal $\alpha$-subunits do not form heterotetramers. Thus, if we consider only Shaker family $\alpha$-subunit genes for the moment, three possibilities exist: (1) the somatic $I_{\mathrm{A}} \mathrm{s}$ are carried by shaker channels alone; (2) 
the somatic $I_{\mathrm{A}} \mathrm{s}$ are carried by two different populations of A-channels, one containing shal $\alpha$-subunits and the other containing shaker $\alpha$-subunits; (3) the somatic $I_{\mathrm{A}} \mathrm{s}$ are carried by shal channels alone. Because the size of the somatic $I_{\mathrm{A}}$ varies as a linear function of shal transcript number with $p<0.001$, and pyloric somatic $I_{\mathrm{A}} \mathrm{s}$ qualitatively resemble lobster $I_{\text {shal }}$ but not lobster $I_{\text {shaker }}$, we can rule out the first possibility. With regard to the second possibility, the extremely high $R^{2}$ value for the shal $-I_{\mathrm{A}}$ correlation (Fig. 8) suggests that any significant contribution to the somatic $I_{\mathrm{A}}$ from the shaker gene must either (1) remain fairly constant among cell types or (2) vary among cell types in a manner that is essentially identical to shal. If, on the one hand, the shaker gene produced a significant, constant number of somatic A-channels in every cell type, then there should be a sizable $I_{\mathrm{A}}$ even when shal transcripts are absent. In other words, when $x$ is zero in Figure 8, the $y$-intercept should be positive. Because the extrapolated $y$-intercept in Figure 8 is negative, we can discard this possibility. If, on the other hand, the ratio of somatic shaker to shal channels is constant among the six different cell types, then shaker and shal gene expression must be completely coregulated in these six different cell types. However, strict coregulation of shaker and shal A-channel gene expression has not been described in previous studies in other systems (Roberds and Tamkun, 1991; Kues and Wunder, 1992; Lesage et al., 1992; Sheng et al., 1992; Tsaur et al., 1992; Dixon and McKinnon, 1994, 1996; Maletic-Savatic et al., 1995; Brahmajothi et al., 1996; Serôdio et al., 1996) (for review, see Chandy and Gutman, 1995). Because we have not yet quantified shaker expression in pyloric neurons, we cannot reject the possibility of coregulation categorically. Nevertheless, because the pyloric somatic $I_{\mathrm{A}} \mathrm{s}$ resemble lobster $I_{\text {shal }}$ more than lobster $I_{\text {shaker }}$, we suggest that the third possibility is the simplest and most likely: in pyloric neurons the shal gene encodes most or all of the Shaker family $\alpha$-subunits for somatic A-channels. This point eventually could be confirmed by demonstrating a causal relationship between shal and $I_{\mathrm{A}}$, using shaker and shal knock-out techniques that use expression of antisense oligonucleotides (Chung et al., 1995) or dominantnegative mutations (Ribera, 1996).

The previous argument involved Shaker family $\alpha$-subunits only. This argument did not consider the formation of heterotetramers between Shaker family $\alpha$-subunits and other proteins. Drosophila mutant analysis indicates that Shaker family proteins might form heterotetramers with non-Shaker family $\mathrm{K}^{+}$channel proteins such as EAG (Warmke et al., 1991; Zhong et al., 1991, 1993; Warmke and Ganetzky, 1994), and shaker and EAG have been shown to form heterotetramers in an oocyte expression system (Chen et al., 1996). Similarly, heterotetramers can form between shal $\alpha$ and $\gamma$ subunits (Jegla and Salkoff, 1997). Our data do not rule out the possibility that some fraction, or even all, of the somatic A-channels are heterotetramers between $\alpha$-subunits and EAG, $\gamma$-subunits, or other as yet unidentified subunits.

\section{DISCUSSION}

$I_{\mathrm{A}}$ diversity in the 14-neuron pyloric network of the spiny lobster, Panulirus interruptus, is established by varying the density and/or the properties of A-channels between cells. Arthropod A-channels are multimeric proteins containing Shaker family $\alpha$-subunits encoded by either the shaker or shal gene in addition to other subunits (Salkoff et al., 1992; M. Kim et al., 1995, 1996; Tsunoda and Salkoff, 1995a,b; Baro et al., 1996a) (M. Kim, D. Baro, C. Lanning, M. Doshi, J. Farnham, H. Moskowitz, J. Peck, B. Olivera, and R. Harris-Warrick, unpublished data). Our voltage-clamp studies demonstrated that the pyloric $I_{\mathrm{A}} \mathrm{s}$ are more similar to lobster $I_{\text {shal }}$ than lobster $I_{\text {shaker }}$ Quantitative SC-RTPCR experiments show that there is an exceptionally strong linear correlation between the magnitude of the somatic $I_{\mathrm{A}}$ and the number of shal transcripts in pyloric neurons. The two most likely interpretations of these data are either that shal channels underlie the major component of the somatic $I_{\mathrm{A}}$ or that an unchanging ratio of shaker to shal channels underlies the somatic $I_{\mathrm{A}}$ in all pyloric neurons.

\section{Somatic $I_{A}$ heterogeneity in the pyloric network}

Our results suggest that although lobster shal $\alpha$-subunits or a constant ratio of shaker to shal $\alpha$-subunits underlies the somatic $I_{\mathrm{A}}$ in pyloric neurons, the $I_{\mathrm{A}} \mathrm{s}$ vary dramatically in their biophysical properties, depending on which cell is expressing the gene or genes. For example, the LP cell has more shal transcripts than the PY cell and more somatic A-channels (as determined from the average corrected or uncorrected $G_{\max }$; Fig. 3). However, the somatic $I_{\mathrm{A}}$ is smaller in the LP cell at all submaximal activating voltages. This is because the LP activation curve is shifted in the depolarizing direction relative to the PY so that at any physiological membrane potential fewer A-channels will be open in the LP cell (Fig. 2, Table 1).

Qualitative and quantitative differences in Shaker family $\alpha$-subunit gene expression do not seem to underlie the biophysical differences in the LP and PY $I_{\mathrm{A}} \mathrm{s}$. Stable cell-specific variation in the post-translational modifications of A-channels could be partially responsible for $I_{\mathrm{A}}$ diversity in the pyloric network (Levitan, 1994; Holmes et al., 1996; Jonas and Kaczmarek, 1996; Villarroel and Schwarz, 1996; Harris-Warrick et al., 1997; Keros and McBain, 1997). Because a single lobster shal $\alpha$-subunit has at least 31 putative protein kinase sites (Baro et al., 1996a) and the same neuromodulator can alter pyloric somatic $I_{\mathrm{A}} \mathrm{s}$ differentially (Harris-Warrick et al., 1995a,b; Levini et al., 1996; P. Kloppenburg, unpublished data), it is possible that cell-specific differences in constitutive cycles of $\alpha$-subunit phosphorylation-dephosphorylation reproducibly alter pyloric cell $I_{\mathrm{A}} \mathrm{s}$.

Other mechanisms also could contribute to pyloric $I_{\mathrm{A}}$ diversity. For instance, it has been shown recently that the Shaker gene family encodes both classical $\alpha$-subunits and regulatory $\gamma$-subunits. Classical $\alpha$-subunits like shaker (Kv1), shab (Kv2), shaw (Kv3), shal (Kv4), and Kv5 are membrane-spanning subunits that can form functional homotetramers and contain a subset of 44 amino acids that are totally conserved across subfamilies and species (Chandy and Gutman, 1995). Although the definition of $\gamma$-subunits is still evolving, it seems that $\gamma$-subunits like Kv6, Kv7, Kv8, and shal $\gamma 1$ are regulatory membrane-spanning subunits that cannot form functional homotetramers and contain alterations in a few of the 44 amino acids that are totally conserved in all classical $\alpha$-subunits (Drewe et al., 1992; Hugnot, 1996; Jegla and Salkoff, 1997). $\gamma$-Subunits can form heteromultimers with classical $\alpha$-subunits and change the properties of the $\mathrm{K}^{+}$channel (Hugnot et al., 1996; Jegla and Salkoff, 1997). Jegla and Salkoff (1997) have shown recently that shal $\alpha$ and $\gamma$ subunits interact in a constant stoichiometry. Thus, the number of $\alpha$-subunit transcripts might help to determine the number of A-channels in a pyloric cell, whereas different $\gamma$-subunits in different cell types could alter the biophysical properties of those A-channels. Cell-specific alternate splicing of the $\alpha$-subunit transcripts (Mottes and Iverson, 1995; Rogero and Tejedor, 1995) and/or $\beta$-subunit or other protein interactions with the $\alpha$-subunits could alter $I_{\mathrm{A}} \mathrm{s}$, although to date no shal $\beta$-subunits have been reported (Rudy et al., 1988; Chabala et al., 1993; Rettig et al., 
1994; Serôdio et al., 1994; Chouinard et al., 1995; England et al., 1995; E. Kim et al., 1995; Majumder et al., 1995; McCormack et al., 1995; Morales et al., 1995; Rhodes et al., 1995, 1996; Cohen et al., 1996; Nakahira et al., 1996; Sewing et al., 1996; Shi et al., 1996; Yu et al., 1996; Tejedor et al., 1997). Finally, the same $\alpha$-subunits could produce different $I_{\mathrm{A}} \mathrm{s}$ if the composition of the cellular membranes were distinct in different cells (Coronado et al., 1984; Barrantes, 1993; Bhushan and McNamee, 1993; Chang et al., 1995).

\section{The VD $I_{\mathrm{A}}$}

The VD $I_{\mathrm{A}}$ is significantly different from the other pyloric neurons: it is much smaller, more rapidly inactivating, and both the activation and inactivation curves are more hyperpolarized (Fig. 2 , Tables 1,2$)$. With uncorrected $G_{\max }$ values, the VD data point does not lie on or near the line relating $I_{\mathrm{A}} G_{\max }$ to shal transcript number, as do the data points from all the other pyloric neurons (Fig. 8A). There are at least three possible interpretations of these data, and they are not mutually exclusive. The first interpretation is that shaker contributes more substantially to the VD $I_{\mathrm{A}}$ than to other pyloric $I_{\mathrm{A}} \mathrm{s}$. The second interpretation is that most VD somatic A-channels contain shal $\alpha$-subunits, but a greater fraction of VD shal channels are "silenced" under control conditions relative to other pyloric cells. The third interpretation is that the VD falls off the line in Figure $8 A$ because, as shown in Figure 1, the more rapid inactivation of the VD $I_{\mathrm{A}}$ produces a significant underestimate of the true VD $G_{\max }$ relative to the other pyloric cell types. To compensate for this error, we have used the corrected $G_{\max }$ as a measure of $I_{\mathrm{A}}$ magnitude. As seen in Figure $8 B$, plotting the corrected $G_{\max }$ versus transcript number causes the VD to lie much closer to the line, suggesting that shal does underlie $I_{\mathrm{A}}$ in the VD cell as well. Unfortunately, because of the more rapid inactivation, the correction procedure will be the most inaccurate for the VD cell (Willms, 1997). Thus this issue is not resolved and we cannot state conclusively which, if any, of these three possibilities is correct.

\section{If shal underlies the somatic $I_{A}$, where are the shaker A-channels?}

We have shown with nonquantitative methods that shaker is expressed in all pyloric neurons and that shaker produces A-channels (Fig. 2; Baro et al., 1996b), yet in our more favored interpretation of the data, shal accounts for the majority of somatic A-channel $\alpha$-subunits. One possible explanation for this apparent discrepancy is that most shaker A-channels may be localized to axons and nonclamped regions of the neuropil. In Drosophila, shaker channels are more highly concentrated in the axons and neuropil of adult brains and are not the major component of somatic $I_{\mathrm{A}} \mathrm{s}$ in most neurons (Solc et al., 1987; Baker and Salkoff, 1990; Schwarz et al., 1990; Tsunoda and Salkoff, 1995a,b). Similarly, in the mammalian brain, shal channels (Kv4.2) are concentrated in the somatodendritic compartment, whereas shaker A-channels (Kv1.4) are localized to axons and terminals (Sheng et al., 1992; Maletic-Savatic et al., 1995; Veh et al., 1995).

Electrophysiological analyses of Drosophila mutants indicate that shal encodes the somatic $I_{\mathrm{A}}$ in most embryonic neurons (Tsunoda and Salkoff, 1995a,b). Moreover, hybrid arrest studies on rat brain mRNA expressed in Xenopus oocytes have shown that shal (Kv4.2), but not shaker (Kv1.4), mRNA underlies the somatic transient $\mathrm{K}^{+}$current $\left(I_{\mathrm{SA}}\right)$ recorded from rat thalamic and cerebellar neurons (Serôdio et al., 1994). Finally, Dixon and McKinnon (1996) suggest that members of the shal (Kv4) subfamily are likely to underlie the low-threshold somatic $I_{\mathrm{A}}$ in sympathetic neurons, whereas shaker A-channels (Kv1.4) do not make a significant contribution to this current.

Note that our proposal does not imply that shal channels are localized only to the soma and therefore are excluded from the distal regions of the neuropil. Shal channels may be distributed over the entire surface of a pyloric neuron, in which case they certainly can affect neuronal activity and firing patterns. We have shown previously that dopamine modulation of the measured somatic $I_{\mathrm{A}}$ can explain quantitatively the alterations in the postinhibitory rebound characteristics of the LP and PY neurons (Harris-Warrick et al., 1995a,b). Thus, either the somatic $I_{\mathrm{A}}$ contributes to neuronal firing patterns, and/or the A-channels present in the soma are also likely to be found in the neuropil. Interestingly, recent work from Drosophila suggests that shal channels are present in the membrane of Type III synaptic boutons (Martínez-Padrón and Ferrús, 1997).

\section{shal transcripts and the somatic $I_{\mathrm{A}}$}

It was somewhat surprising to find such a simple relationship between shal transcript number and the $I_{\mathrm{A}} G_{\max }$. Any number of phenomena could have masked this relationship. If there were large cell-specific differences in the translational regulation of shal such that some cells produced $10^{3}$ functional proteins per transcript whereas others produced one, then the size of $I_{\mathrm{A}}$ would not correlate with the number of shal transcripts. Similarly, if two cells had the same number of shal transcripts and proteins, but the first cell concentrated all of its shal channels in the soma whereas the second localized them to the unclamped regions of the neuropil, we would detect an $I_{\mathrm{A}}$ in the first cell, no $I_{\mathrm{A}}$ in the second cell, and no positive correlation between transcript number and $I_{\mathrm{A}}$ magnitude. By the same token, if the average conductance of somatic A-channels varied significantly among pyloric neurons, then the $R^{2}$ values in Figure 8 would be reduced dramatically even if shal encoded the $\alpha$-subunits of the somatic $I_{\mathrm{A}}$. The fact that we can demonstrate an unequivocal linear relationship between shal transcript number and the size of the somatic $I_{\mathrm{A}}$ suggests that translational regulation, shal channel localization (the fraction of shal channels in voltage-clamped vs nonvoltageclamped regions), and average somatic A-channel conductance do not vary substantially among the 14 neurons of the pyloric network under control conditions.

The fact that the $x$-intercept in Figure 8 is not zero suggests that there is a sizable pool of unused shal RNA in these cells. Some portions of the transcripts we measure almost certainly are processed incompletely or incorrectly (Kramer, 1996) or partially degraded (Jacobson and Peltz, 1996) and therefore would yield no functional protein. In addition, shal gene expression could be regulated post-transcriptionally so that some of the transcripts are being stored rather than actively translated (Curtis et al., 1995; Decker and Parker, 1995; Hentze, 1995; Jansen et al., 1995; Wymore et al., 1996).

\section{Conclusion}

The most parsimonious explanation of the linear relationship between shal gene expression and $I_{\mathrm{A}} G_{\max }$ is that shal encodes the Shaker family $\alpha$-subunits for somatic A-channels in most or all of the pyloric neurons. If shaker plays a significant role, its expression must be coregulated exactly with shal. In either case, it does not appear that pyloric $I_{\mathrm{A}}$ heterogeneity is attributable to varying ratios of shaker to shal channels in different cell types. Stable differences in Shaker family $\alpha$-subunit gene expression correlate with the variations in somatic A-channel density among cell 
types; however, differences in Shaker family $\alpha$-subunit gene expression do not underlie the differences in the biophysical properties of the six pyloric $I_{\mathrm{A}} \mathrm{s}$. Other phenomena, including posttranslational modifications and auxiliary subunits, must be responsible for the variety of different $I_{\mathrm{A}}$ s seen in pyloric neurons.

\section{REFERENCES}

Baker K, Salkoff L (1990) The Drosophila shaker gene codes for a distinctive $\mathrm{K}^{+}$current in a subset of neurons. Neuron 2:129-140.

Banks MI, Haberly LB, Jackson MB (1996) Layer-specific properties of the transient $\mathrm{K}$ current $\left(I_{\mathrm{A}}\right)$ in piriform cortex. $\mathrm{J}$ Neurosci 16:3862-3876.

Baro DJ, Coniglio LM, Cole CL, Rodriguez HE, Lubell JK, Kim MT, Harris-Warrick RM (1996a) Lobster shal: comparison with Drosophila shal and native potassium currents in identified neurons. J Neurosci 16:1689-1701.

Baro DJ, Cole CL, Harris-Warrick RM (1996b) RT-PCR analysis of shaker, shab, shaw, and shal gene expression in single neurons and glial cells. Receptors Channels 4:149-159.

Barrantes FJ (1993) Structural-functional correlates of the nicotinic acetylcholine receptor and its lipid microenvironment. FASEB J 7:1460-1467.

Bhushan A, McNamee MG (1993) Correlation of phospholipid structure with functional effects on the nicotinic acetylcholine receptor. Biophys J 64:716-723.

Brahmajothi MV, Morales MJ, Liu S, Rasmusson RL, Campbell DL, Strauss HC (1996) In situ hybridization reveals extensive diversity of $\mathrm{K}^{+}$channel mRNA in isolated ferret cardiac myocytes. Circ Res 78:1083-1089.

Cassell JF, McLachlan EM (1986) The effect of a transient outward current $\left(I_{\mathrm{A}}\right)$ on synaptic potentials in sympathetic ganglion cells of the guinea-pig. J Physiol (Lond) 374:273-288.

Cassell JF, Clark AL, McLachlan EP (1986) Characteristics of phasic and tonic sympathetic ganglion cells of the guinea-pig. J Physiol (Lond) 372:457-483.

Chabala LD, Bakry N, Covarrubias M (1993) Low molecular weight poly $\left(\mathrm{A}^{+}\right)$mRNA species encode factors that modulate gating of a non-shaker A-type $\mathrm{K}^{+}$channel. J Gen Physiol 102:713-728.

Chandy CK, Gutman GA (1995) Voltage-gated potassium channel genes. In: Handbook of receptors and channels: ligand- and voltagegated ion channels (North RA, ed), pp 1-71. Boca Raton: CRC.

Chang HM, Reitstetter R, Gruener R (1995) Lipid-ion channel interactions: increasing phospholipid headgroup size, but not ordering acyl chains, alters reconstituted channel behavior. J Membr Biol 145:13-19.

Chen M-L, Hoshi T, Wu C-F (1996) Heteromultimeric interactions among K ${ }^{+}$channel subunits from Shaker and eag families in Xenopus oocytes. Neuron 17:535-542.

Chouinard SW, Wilson GF, Schlimgen AK, Ganetzky B (1995) A potassium channel $\beta$-subunit related to the aldo-keto reductase superfamily is encoded by the Drosophila hyperkinetic locus. Proc Natl Acad Sci USA 92:6763-6767.

Chung S, Saal DB, Kaczmarek LK (1995) Elimination of potassium channel expression by antisense oligonucleotides in a pituitary cell line. Proc Natl Acad Sci USA 92:5955-5959.

Cohen NA, Brenman JE, Snyder SH, Bredt DS (1996) Binding of the inward rectifier $\mathrm{K}^{+}$channel $\mathrm{K}$ ir 2.3 to PSD-95 is regulated by protein kinase A phosphorylation. Neuron 17:759-767.

Connor JA (1975) Neural repetitive firing: a comparative study of membrane properties of crustacean walking leg axons. J Neurophysiol 351:922-932.

Coronado R, Latorre R, Mautner HG (1984) Single potassium channels with delayed rectifier behavior from lobster axon membranes. Biophys J 45:289-299.

Covarrubias M, Wei AA, Salkoff L (1991) Shaker, shal, shab, and shaw express independent $\mathrm{K}^{+}$current systems. Neuron 7:763-773.

Curtis D, Lehmann R, Zamore PD (1995) Translational regulation in development. Cell 81:171-178.

Deal KK, Lovinger DM, Tamkun MM (1994) The brain Kv1.1 potassium channel: in vitro and in vivo studies on subunit assembly and post-translational processing. J Neurosci 14:1666-1676.

Decker CJ, Parker R (1995) Diversity of cytoplasmic functions for the $3^{\prime}$ untranslated region of eukaryotic transcripts. Curr Opin Cell Biol 7:386-392.

Drewe JA, Verma S, Frech G, Joho RH (1992) Distinct spatial and temporal expression patterns of $\mathrm{K}^{+}$channel messenger RNAs from different subfamilies. J Neurosci 12:538-548.

Dixon JE, McKinnon D (1994) Quantitative analysis of potassium channel mRNA expression in atrial and ventricular muscles of rats. Circ Res 75:252-260.

Dixon JE, McKinnon D (1996) Potassium channel mRNA expression in prevertebral and paravertebral sympathetic neurons. Eur J Neurosci 8:183-191.

Eisen JS, Marder E (1982) Mechanisms underlying pattern generation in lobster stomatogastric ganglion as determined by selective inactivation of identified neurons. III. Synaptic connections of electrically coupled pyloric neurons. J Neurophysiol 48:1392-1415.

England S, Uebele VN, Shear H, Kodali J, Bennett PB, Tamkun MM (1995) Characterization of a voltage-gated $\mathrm{K}^{+}$channel $\beta$ subunit expressed in human heart. Proc Natl Acad Sci USA 92:6309-6313.

Ferre F (1992) Quantitative or semi-quantitative PCR: reality versus myth. PCR Methods Appl 2:1-9.

Foley KR, Leonard MW, Engel JD (1993) Quantitation of RNA using the polymerase chain reaction. Trends Genet 9:380-385.

Furakawa Y, Kandel E, Pfaffinger P (1992) Three types of early transient potassium currents in Aplysia neurons. J Neurosci 12:989-1000.

Gause WC, Adamovicz J (1994) The use of PCR to quantitate gene expression. PCR Methods Appl 3[Suppl 6]:123-135.

Graubard K, Hartline DK (1991) Voltage-clamp analysis of intact stomatogastric neurons. Brain Res 557:241-254.

Hamill OP, Huguenard JJ, Prince DA (1991) Patch-clamp studies of voltage-gated currents in identified neurons of the rat cerebral cortex. Cereb Cortex 1:48-61.

Harris-Warrick RM, Marder E, Selverston AI, Moulins M (1992) Dynamic biological networks: the stomatogastric nervous system. Cambridge, MA: MIT.

Harris-Warrick RM, Coniglio LM, Barazangi N, Guckenheimer J, Gueron S (1995a) Dopamine modulation of transient potassium current evokes phase shifts in a central pattern generator network. J Neurosci 15:342-358.

Harris-Warrick RM, Coniglio LM, Levini RM, Gueron S, Guckenheimer J (1995b) Dopamine modulation of two subthreshold currents produces phase shifts in activity of an identified motoneuron. J Neurophysiol 74:1404-1420.

Harris-Warrick RM, Baro DJ, Coniglio LM, Johnson BR, Levini RM, Peck JH, Zhang B (1997) Chemical modulation of crustacean stomatogastric pattern generator networks. In: Neurons networks and motor behavior (Stein PSG, Grillner S, Selverston AI, Stuart DG, eds). Cambridge, MA: MIT.

Hartline DK (1979) Pattern generation in the lobster (Panulirus) stomatogastric ganglion. II Pyloric network simulation. Biol Cybern 33:223-236.

Hartline DK, Graubard K (1992) Cellular and synaptic properties in the crustacean stomatogastric nervous system. In: Dynamic biological networks: the stomatogastric nervous system (Harris-Warrick RM, Marder E, Selverston AI, Moulins M, eds), pp 31-85. Cambridge, MA: MIT.

Hartline DK, Gassie DV, Jones BR (1993) Effects of soma isolation on outward currents measured under voltage clamp in spiny lobster stomatogastric motor neurons. J Neurophysiol 69:2056-2071.

Henikoff S (1987) Unidirectional digestions with ExoIII in DNA sequence analysis. Methods Enzymol 155:156-165.

Hentze M-W (1995) Translational regulation: versatile mechanisms for metabolic and developmental control. Curr Opin Cell Biol 7:393-398.

Holmes TC, Fadool DA, Levitan IB (1996) Tyrosine phosphorylation of the Kv1.3 potassium channel. J Neurosci 16:1581-1590.

Hugnot J-P, Salinas M, Lesage F, Guillemare E, de Weille J, Heurteaux C, Mattéi M-G, Lazdunski M (1996) Kv8.1, a new neuronal potassium channel subunit with specific inhibitory properties towards Shab and Shaw channels. EMBO J 15:3322-3331.

Jansen M, DeMoore CH, Sussenbach JS, Brande JLVD (1995) Translational control of gene expression. Pediatr Res 37:681-686.

Jacobson A, Peltz SW (1996) Interrelationships of the pathways of mRNA decay and translation in eukaryotic cells. Annu Rev Biochem 65:693-739.

Jegla T, Salkoff L (1997) A novel subunit for shal $\mathrm{K}^{+}$channels radically alters activation and inactivation. J Neurosci 17:32-44.

Jonas EA, Kaczmarek LK (1996) Regulation of potassium channels by protein kinases. Curr Opin Neurobiol 6:318-323.

Keros S, McBain C (1997) Arachidonic acid inhibits transient potassium currents and broadens action potentials during electrographic seizures 
in hippocampal pyramidal and inhibitory interneurons. J Neurosci 17:3476-3487.

Kim E, Niethammer M, Rothschild A, JanYN, Sheng M (1995) Clustering of Shaker-type $\mathrm{K}^{+}$channels by interaction with a family of membrane-associated guanylate kinases. Nature 378:85-88.

Kim MT, Baro DJ, Yuan A, Cole CL, Tapia M, Podleski TP, HarrisWarrick RM (1995) Cloning and quantifying levels of shaker gene expression in pyloric neurons. Soc Neurosci Abstr 21:149.

Kim MT, Baro DJ, Cole CL, Doshi M, Moskowitz HS, Podleski T, Harris-Warrick RM (1996) Alternatively spliced pore-lining regions in Panulirus shaker. Soc Neurosci Abstr 22:1248.

Kramer A (1996) The structure and function of proteins involved in mammalian pre-mRNA splicing. Annu Rev Biochem 65:367-409.

Kues WA, Wunder F (1992) Heterogeneous expression patterns of mammalian potassium channel genes in developing and adult rat brain. Eur J Neurosci 4:1296-1308.

Lee TE, Philipson LH, Kuznetsov A, Nelson DJ (1994) Structural determinants for assembly of mammalian $\mathrm{K}^{+}$channels. Biophys $\mathrm{J}$ 66:667-673.

Lesage F, Attali B, Lazdunski M, Barhanin J (1992) Developmental expression of voltage-sensitive $\mathrm{K}^{+}$channels in mouse skeletal muscle and $\mathrm{C}_{2} \mathrm{C}_{12}$ cells. FEBS Lett 310:162-166.

Levini RM, Peck J, Harris-Warrick RM (1996) The ionic basis of dopamine inhibition of PD neurons in the pyloric network of the lobster stomatogastric ganglion. Soc Neurosci Abstr 22:2046.

Levitan IB (1994) Modulation of ion channels by protein phosphorylation and dephosphorylation. Annu Rev Physiol 56:193-212.

Li M, Jan YN, Jan LY (1992) Specification of subunit assembly by the hydrophobic amino-terminal domain of the shaker potassium channel. Science 257:1225-1230.

Liu D-W, Gintant GA, Antzelevitch C (1993) Ionic basis for electrophysiological distinctions among epicardial midmyocardial and endocardial myocytes from the free wall of the canine left ventricle. Circ Res 72:671-687.

Majumder K, De Biasi M, Wang Z, Wible BA (1995) Molecular cloning and functional expression of a novel potassium channel beta-subunit from human atrium. FEBS Lett 361:13-16.

Maletic-Savatic M, Lenn NJ, Trimmer JS (1995) Differential spatiotemporal expression of $\mathrm{K}^{+}$channel polypeptides in rat hippocampal neurons developing in situ and in vitro. J Neurosci 15:3840-3851.

Marder E, Calabrese RL (1996) Principles of rhythmic motor pattern generation. Physiol Rev 76:687-717.

Martínez-Padrón M, Ferrús A (1997) Presynaptic recordings from Drosophila: correlation of macroscopic and single channel $\mathrm{K}^{+}$currents. J Neurosci 17:3412-3424.

Massengill JL, Smith MA, Son DI, O’Dowd DK (1997) Differential expression of $\mathrm{K}_{4-\mathrm{AP}}$ currents and $\mathrm{Kv} 3.1$ potassium channel transcripts in cortical neurons that develop distinct firing phenotypes. J Neurosci 17:3136-3147.

McCormack K, McCormack T, Tanouye M, Rudy B, Stuhmer W (1995) Alternative splicing of the human shaker $\mathrm{K}^{+}$channel $\beta 1$ gene and functional expression of the $\beta 2$ gene product. FEBS Lett 370:32-36.

Morales MJ, Castellino RC, Crews AL, Rasmusson R, Strauss HC (1995) A novel beta subunit increases rate of inactivation of specific voltagegated potassium channel alpha subunits. J Biol Chem 270:6272-6277.

Mottes JR, Iverson LE (1995) Tissue-specific alternative splicing of hybrid shaker-lacZ genes correlates with kinetic differences in shaker $\mathrm{K}^{+}$ currents in vivo. Neuron 14:613-623.

Nakahira K, Shi G, Rhodes K, Trimmer JS (1996) Selective interactions of voltage-gated $\mathrm{K}^{+}$channel $\beta$-subunits with $\alpha$-subunits. J Biol Chem 271:7084-7089.

Premack BA, Thompson S, Coombs-Hahn J (1989) Clustered distribution and variability in kinetics of transient $\mathrm{K}$ channels in molluscan neuron cell bodies. J Neurosci 9:4089-4099.

Rettig J, Heinemann SH, Wunder F, Lorra C, Parcej DN, Dolly JO, Pongs O (1994) Inactivation properties of voltage-gated $\mathrm{K}^{+}$channels altered by presence of $\beta$-subunit. Nature 369:289-294.

Rhodes KJ, Keilbough SA, Barrezueta NX, Lopez KL, Trimmer JS (1995) Association and colocalization of $\mathrm{K}^{+}$channel $\alpha$ - and $\beta$-subunit polypeptides in rat brain. J Neurosci 15:5360-5371.

Rhodes KJ, Monaghan MM, Barrezueta NX, Nawoschik S, BekeleArcuri Z, Matos MF, Nakahira K, Schechter LE, Trimmer JS (1996) Voltage-gated $\mathrm{K}^{+}$channel $\beta$ subunits: expression and distribution of $\mathrm{Kv} \beta 1$ and $\mathrm{Kv} \beta 2$ in adult rat brain. J Neurosci 16:4846-4860.
Ribera AB (1996) Homogeneous development of electrical excitability via heterogeneous ion channel expression. J Neurosci 16:1123-1130.

Roberds SL, Tamkun MM (1991) Cloning and tissue-specific expression of five voltage-gated potassium channel cDNAs expressed in rat heart. Proc Natl Acad Sci USA 88:1798-1802.

Rogero O, Tejedor FJ (1995) Immunochemical characterization and developmental expression of shaker potassium channels from the nervous system of Drosophila. J Biol Chem 270:25746-25751.

Rudy B, Hoger JH, Lester HA, Davidson N (1988) At least two mRNA species contribute to the properties of rat brain A-type potassium channels expressed in Xenopus oocytes. Neuron 1:649-658.

Salkoff L, Baker K, Butler A, Covarrubias M, Pak MD, Wei A (1992) An essential "set" of $\mathrm{K}^{+}$channels conserved in flies, mice, and humans. Trends Neurosci 15:161-166.

Sambrook J, Fritsch EF, Maniatis T (1989) Molecular cloning: a laboratory manual, 2nd Ed. Cold Spring Harbor, NY: Cold Spring Harbor Laboratory.

Schwarz TL, Papazian DM, Carretto RC, Jan Y-N, Jan LY (1990) Immunological characterization of potassium channel components from the Shaker locus and differential distribution of splicing variants in Drosophila. Neuron 4:119-127.

Selverston AI, Moulins M (1987) The crustacean stomatogastric system. Berlin: Springer.

Selverston AI, Russell DF, Miller JP, King DG (1976) The stomatogastric nervous system: structure and function of a small neural network. Prog Neurobiol 7:215-290.

Serôdio P, Kentros C, Rudy B (1994) Identification of molecular components of A-type channels activating at subthreshold potentials. J Neurophysiol 72:1516-1529.

Serôdio P, Vega-Saenz de Miera E, Rudy B (1996) Cloning of a novel component of A-type $\mathrm{K}^{+}$channels operating at subthreshold potentials with unique expression in heart and brain. $J$ Neurophysiol 75:2174-2179.

Serrano EE, Getting PA (1989) Diversity of the transient outward potassium current in somata of identified molluscan neurons. J Neurosci 9:4021-4032.

Sewing S, Roeper J, Pongs O (1996) Kv $\beta 1$ subunit binding specific for shaker-related potassium channel $\alpha$ subunits. Neuron 16:455-463.

Shahidullah M, Hoshi N, Yokoyama S, Higashida H (1996) Microheterogeneity in heteromultimeric assemblies formed by shaker (Kv1) and shaw (Kv3) subfamilies of voltage-gated $\mathrm{K}^{+}$channels. Soc Neurosci Abstr 22:1754.

Shen NV, Pfaffinger P (1995) Molecular recognition and assembly sequences involved in the subfamily-specific assembly of voltage-gated $\mathrm{K}^{+}$channel subunit proteins. Neuron 14:625-633.

Sheng M, Tsaur M-L, Jan YN, Jan LY (1992) Subcellular segregation of two A-type $\mathrm{K}^{+}$channel proteins in rat central neurons. Neuron 9:271-284.

Sheng M, Liao YJ, Jan YN, Jan LY (1993) Presynaptic A-current based on heteromultimeric $\mathrm{K}^{+}$channels detected in vivo. Nature 365:72-75.

Shi G, Nakahira K, Hammond S, Rhodes KJ, Schechter LE, Trimmer JS (1996) Beta subunits promote $\mathrm{K}^{+}$channel surface expression through effects early in biosynthesis. Neuron 16:843-852.

Simmers J, Meyrand P, Moulins M (1995) Dynamic networks of neurons. Am Sci 83:262-268.

Solc CK, Zagotta WN, Aldrich RW (1987) Single-channel and genetic analyses reveal two distinct A-type potassium channels in Drosophila. Science 236:1094-1098.

Sucher NJ, Deitcher DL (1995) PCR and patch-clamp analysis of single neurons. Neuron 14:1095-1100.

Tejedor FJ, Bokhari A, Rogero O, Gorczyca M, Zhang J, Kim E, Sheng M, Budnik V (1997) Essential role for $d l g$ in synaptic clustering of shaker $\mathrm{K}^{+}$channels in vivo. J Neurosci 17:152-159.

Tierney AJ, Harris-Warrick RM (1992) Physiological role of the transient potassium current in the pyloric circuit of the lobster stomatogastric ganglion. J Neurophysiol 67:599-609.

Tsaur M-L, Sheng M, Lowenstein DH, Jan YN, Jan LY (1992) Differential expression of $\mathrm{K}^{+}$channel mRNAs in the rat brain and downregulation in the hippocampus following seizures. Neuron 8:1055-1067.

Tsunoda S, Salkoff L (1995a) Genetic analysis of Drosophila neurons: shal, shaw, and shab encode most embryonic potassium currents. J Neurosci 15:1741-1754.

Tsunoda S, Salkoff L (1995b) The major delayed rectifier in both Drosophila neurons and muscle is encoded by shab. J Neurosci 15:5209-5221. 
Veh RW, Lichtinghagen R, Sewing S, Wunder F, Grumbach IM, Pongs O (1995) Immunohistochemical localization of five members of the Kv1 channel subunits: contrasting subcellular locations and neuron-specific colocalizations in rat brain. Eur J Neurosci 7:2189-2205.

Villarroel A, Schwarz TL (1996) Inhibition of the Kv4 (Shal) family of transient $\mathrm{K}^{+}$currents by arachidonic acid. J Neurosci 16:2522-2531.

Wang H, Kunkel DD, Martin TM, Schwartzkroin PA, Tempel BL (1993) Heteromultimeric $\mathrm{K}^{+}$channels in terminal and juxtaparanodal regions of neurons. Nature 365:75-79.

Warmke J, Ganetzky B (1994) A family of potassium channels related to eag in Drosophila and mammals. Proc Natl Acad Sci USA 91:3438-3442.

Warmke J, Drysdale R, Ganetzky B (1991) A distinct potassium channel polypeptide encoded by the Drosophila eag locus. Science 252:1560-1562.

Willms A (1997) Hodgkin-Huxley models: parameter estimation issues, an application to spike frequency adaptation, and analysis of a subcritical Hopf bifurcation. PhD dissertation, Cornell University, Ithaca, NY. Wymore RS, Negulescu D, Kinoshita K, Kalman K, Aiyars J, Gutman GA, Chandy KG (1996) Characterization of the transcription unit of mouse Kv1.4, a voltage-gated potassium channel gene. J Biol Chem 271:15629-15634.

Xu J, Yu W, Jan YN, Jan LY, Li M (1995) Assembly of voltage-gated potassium channels. J Biol Chem 270:24761-24768.

Yu W, Jia X, Li M (1996) NAB domain is essential for the subunit assembly of both $\alpha-\alpha$ and $\alpha-\beta$ complexes of shaker-like potassium channels. Neuron 16:441-453.

Zhong Y, Wu C-F (1991) Alteration of four identified $\mathrm{K}^{+}$currents in Drosophila muscle by mutations in eag. Science 252:1562-1564.

Zhong Y, Wu C-F (1993) Modulation of different potassium currents in Drosophila: a hypothetical role for the EAG subunit in multimeric $\mathrm{K}^{+}$ channels. J Neurosci 13:4669-4677. 